Prepared in cooperation with the

Pennsylvania Department of Health and the

Pennsylvania Department of Environmental Protection

\title{
Distribution of Indoor Radon Concentrations in Pennsylvania, 1990-2007
}

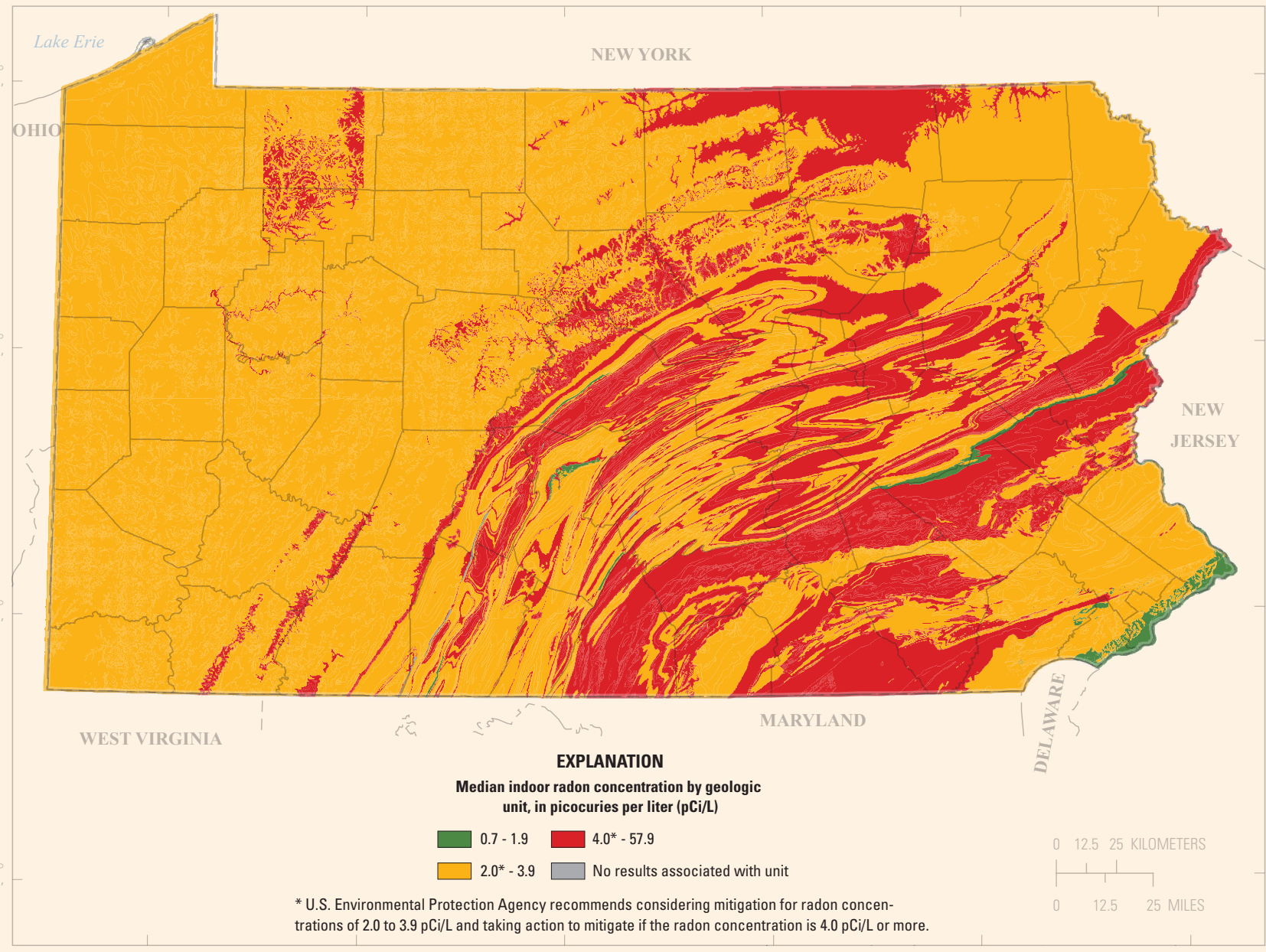

Scientific Investigations Report 2013-5143 
Cover: Map showing geologic units shaded to indicate median indoor radon concentrations in Pennsylvania, 1990-2007 


\section{Distribution of Indoor Radon Concen- trations in Pennsylvania, 1990-2007}

By Eliza L. Gross

Scientific Investigations Report 2013-5143

U.S. Department of the Interior

U.S. Geological Survey 


\section{U.S. Department of the Interior \\ SALLY JEWELL, Secretary}

\section{U.S. Geological Survey \\ Suzette M. Kimball, Acting Director}

U.S. Geological Survey, Reston, Virginia: 2013

For more information on the USGS - the Federal source for science about the Earth, its natural and living resources, natural hazards, and the environment, visit http://Www.usgs.gov or call 1-888-ASK-USGS.

For an overview of USGS information products, including maps, imagery, and publications, visit http://Www.usgs.gov/pubprod

To order this and other USGS information products, visit http://store.usgs.gov

Any use of trade, product, or firm names is for descriptive purposes only and does not imply endorsement by the U.S. Government.

Although this report is in the public domain, permission must be secured from the individual copyright owners to reproduce any copyrighted materials contained within this report.

Suggested citation:

Gross, E.L., 2013, Distribution of indoor radon concentrations in Pennsylvania, 1990-2007: U.S. Geological Survey Scientific Investigations Report 2013-5143, 31 p., http://pubs.usgs.gov/sir/2013/5143/. 


\section{Acknowledgments}

This work was performed under the collaborative sub-grant 5U38EH000191-4 from the Pennsylvania Environmental Public Health Tracking Program of the Pennsylvania Department of Health, Bureau of Epidemiology and the Pennsylvania Department of Environmental Protection. The author would like to thank Robert K. Lewis, PADEP, Bureau of Radiation Protection, Radon Division, for his technical review and for providing the initial indoor radon concentration data used in this study. 



\section{Contents}

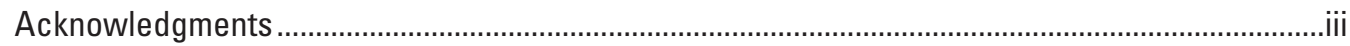

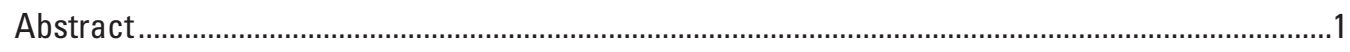

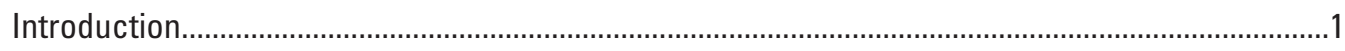

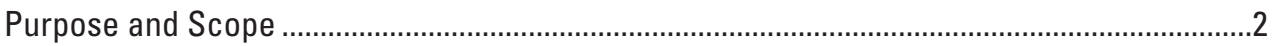

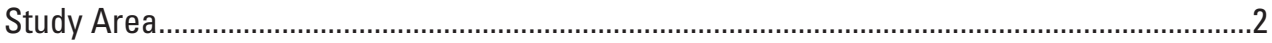

Land Use and Population............................................................................................ 2

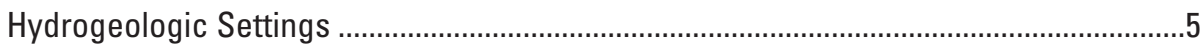

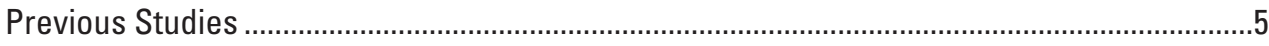

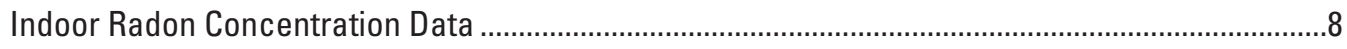

Distribution of Indoor Radon Concentrations .................................................................................

Indoor Radon Concentrations According to Geologic Unit .....................................................

Indoor Radon Concentrations According to Hydrogeologic Setting ......................................11

Uses and Limitations of Aggregated Radon Data .........................................................................15

Summary and Conclusions.......................................................................................................... 15

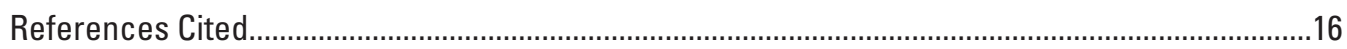




\section{Figures}

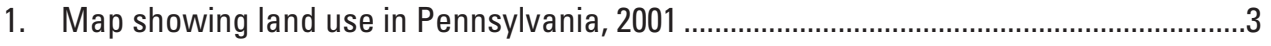

2. Map showing population density in Pennsylvania, 2010................................................4

3. Map showing hydrogeologic settings in Pennsylvania.....................................................6

4. Map showing aerial gamma-ray survey measuring the gamma-ray flux produced by the radioactive decay of the naturally occurring element uranium-238 in Pennsylvania

5. Map showing geologic radon potential for U.S. Environmental Protection Agency, Region 3, adapted from Gunderson and Smoot, 1993.

6. Graph showing frequency of indoor radon concentrations from tests from a database compiled by the Pennsylvania Department of Environmental Protection, Bureau of Radiation Protection, Radon Division

7. Map showing radon test density in Pennsylvania according to geologic unit, 1990-2007

8. Map showing geologic units shaded to indicate median indoor radon concentrations in Pennsylvania, 1990-2007....

9. Map showing hydrogeologic settings shaded to indicate median indoor radon concentrations in Pennsylvania, 1990-2007..... 


\section{Tables}

1. Summary of indoor radon concentrations according to geologic unit in Pennsylvania, 1990-2007 ..............................................................................................18

2. Summary of indoor radon concentrations according to hydrogeologic setting in Pennsylvania, 1990-2007.

\section{Conversion Factors}

Inch/Pound to SI

\begin{tabular}{lcl}
\hline \multicolumn{1}{c}{ Multiply } & By & \multicolumn{1}{c}{ To obtain } \\
\hline square mile $\left(\mathrm{mi}^{2}\right)$ & Area & \\
foot $(\mathrm{ft})$ & 2.59 & square kilometer $\left(\mathrm{km}^{2}\right)$ \\
\hline & 0.305 & meter $(\mathrm{m})$ \\
\hline picocurie per liter $(\mathrm{pCi} / \mathrm{L})$ & Radioactivity & \\
\hline
\end{tabular}

Vertical coordinate information is referenced to the North American Vertical Datum of 1988 (NAVD 88).

Elevation, as used in this report, refers to distance above the vertical datum. 



\title{
Distribution of Indoor Radon Concentrations in Pennsylvania, 1990-2007
}

\author{
By Eliza L. Gross
}

\section{Abstract}

Results from 548,507 indoor radon tests from a database compiled by the Pennsylvania Department of Environmental Protection, Bureau of Radiation Protection, Radon Division, are evaluated in this report in an effort to determine areas where concentrations of radon are highest. Indoor radon concentrations were aggregated according to geologic unit and hydrogeologic setting for spatial analysis. Indoor radon concentrations greater than or equal to the U.S. Environmental Protection Agency (USEPA) action level of 4 picocuries per liter $(\mathrm{pCi} / \mathrm{L})$ were observed for 39 percent of the test results; the highest concentration was $1,866.4 \mathrm{pCi} / \mathrm{L}$.

When analyzed according to Pennsylvania's geologic units, 93 of the 188 (49.5 percent) geologic units with indoor radon concentrations had median concentrations greater than the USEPA action level of $4 \mathrm{pCi} / \mathrm{L}$; most of these geologic units are located in the eastern part of the State and include metamorphic rocks, limestones, sandstones, shales, and glacial deposits. When analyzed according to Pennsylvania's hydrogeologic settings, 5 of the 20 ( 25 percent) settings had median indoor radon concentrations greater than the USEPA action level of $4 \mathrm{pCi} / \mathrm{L}$; these settings are located mostly in the southcentral part of the State.

Median indoor radon concentrations aggregated according to geologic units and hydrogeologic settings are useful for drawing general conclusions about the occurrence of indoor radon in specific geologic units and hydrogeologic settings, but the associated data and maps have limitations. The aggregated indoor radon data have testing and spatial accuracy limitations due to lack of available information regarding testing conditions and the imprecision of geocoded test locations. In addition, the associated data describing geologic units and hydrogeologic settings have spatial and interpretation accuracy limitations, which are a result of using statewide data to define conditions at test locations and geologic data that represent a broad interpretation of geologic units across the State. As a result, indoor air radon concentration distributions are not proposed for use in predicting individual concentrations at specific sites nor for use as a decision-making tool for property owners to decide whether to test for indoor radon concentrations at specific property locations.

\section{Introduction}

Exposure to radon, a colorless, odorless, and radioactive gas, has been identified as the second-leading cause of lung cancer (U.S. Environmental Protection Agency, 1992). Radon-222, the longest-lived radioisotope of radon, is produced by the radioactive decay of radium-226, which is derived from the decay of uranium-238, and is naturally present in soil and bedrock minerals. Radon gas moves from its source in rocks and soils through voids and fractures, and often enters buildings through foundation cracks and other openings. Radon gas can dissolve in groundwater and enter buildings through the use of water-supply wells (Hess and others, 1987; Folger and others, 1994).

Radon gets into the indoor air primarily from soil gas moving up from the soil under homes, though water can be a substantial source in those areas where groundwaters have extreme radon levels (Hess and others, 1987; Folger and others, 1994). Once radon gas enters buildings, it can become trapped, can accumulate, and then can be inhaled by anyone within the building. When inhaled, radon gas and its decay products may accumulate in the lungs and damage lung tissue (World Health Organization, 2009). Typically most radon is exhaled before causing much damage, but radon decay products can become attached to dust, smoke, or other fine particles from the air and remain trapped in the lungs. Accumulation of radioactive elements in constant, close contact with lung tissue can increase cancer risk. The dose-response relation is linear, which means that the risk of lung cancer increases proportionally with increasing radon exposure (National Academy of Science, 1999; World Health Organization, 2006, 2009). Because of this increase in risk, the U.S. Environmental Protection Agency (USEPA) recommends that homeowners consider mitigation of radon for concentrations of 2 to 4 picocuries per liter ( $\mathrm{pCi} / \mathrm{L}$ ) and that homeowners take action to mitigate radon for concentrations of $4 \mathrm{pCi} / \mathrm{L}$ or more (U.S. Environmental Protection Agency, 2011). Outdoor radon levels are usually very low; the average concentration of radon in outdoor air is $0.4 \mathrm{pCi} / \mathrm{L}$, which is one-tenth of the USEPA's action level of $4 \mathrm{pCi} / \mathrm{L}$.

In Pennsylvania, the highest radon concentration $(2,600 \mathrm{pCi} / \mathrm{L})$ ever found in a private residence was measured 
in December 1984 by the Pennsylvania Department of Environmental Protection (PADEP), Bureau of Radiation Protection (Gerusky, 1987; Smith and others, 1987) in the Reading Prong hydrogeologic setting. Since no radon action level was yet established in Pennsylvania in 1984, PADEP examined reports 77 and 78 from the National Council on Radiation Protection and Measurements, which discuss calculations of the potential risk associated with radon exposure and estimates of the risk to the general population from exposure to an assumed average environmental level of radon (National Council on Radiation Protection and Measurements, 1984a, 1984b) . Because of the risk to human health, a house-to-house campaign was established to evaluate radon concentrations in the surrounding neighborhood. The Pennsylvania Department of Health (PADOH) received assistance from the Centers for Disease Control (CDC) to establish a radon concentration of $4 \mathrm{pCi} / \mathrm{L}$ as the accepted criterion for a concentration limit in domestic air.

Today (2012), the PADEP Bureau of Radiation Protection follows the USEPA recommendation that homes receive additional long-term monitoring if initial short-term testing shows radon concentrations of $4 \mathrm{pCi} / \mathrm{L}$ or greater and that homes receive mitigation if radon concentrations of $4 \mathrm{pCi} / \mathrm{L}$ or greater are confirmed (U.S. Environmental Protection Agency, 2012). For example, homeowners will usually start out with shortterm testing (lasting 2 to 90 days). If the result of an initial short-term test is $4 \mathrm{pCi} / \mathrm{L}$ or higher, a second short-term test or a long-term test is recommended. Follow-up long-term tests are recommended to obtain a better understanding of yearround average indoor radon concentrations, whereas followup short-term tests are recommended if results are needed quickly. If the follow-up long-term test result is $4 \mathrm{pCi} / \mathrm{L}$ or more or if the average of the first and second short-term tests is $4 \mathrm{pCi} / \mathrm{L}$ or more, mitigation in the home is recommended. If measured indoor air concentrations are between 2 and $4 \mathrm{pCi} / \mathrm{L}$, the USEPA recommends that homeowners still consider reducing radon levels in homes, because any radon exposure is believed to carry some risk (U.S. Environmental Protection Agency, 2012).

It is important to identify areas in the State that have indoor radon concentrations exceeding the USEPA action level to update, further refine, and identify potential indoor radon problem areas in Pennsylvania. To date, the PADEP Bureau of Radiation Protection, Radon Division has conducted 15 concentrated surveys in areas of known high radon occurrence. The U.S. Geological Survey (USGS), in cooperation with the PADEP and PADOH, initiated a study in 2012 to characterize the distribution of indoor radon concentrations in Pennsylvania and provide information on locations where additional concentrated surveys could be conducted. This distribution information will allow health officials to conduct additional studies, raise awareness, and direct resources towards areas of concern not previously identified.

\section{Purpose and Scope}

This report documents indoor radon concentrations in Pennsylvania during 1990-2007 and their spatial distribution according to geologic units and hydrogeologic settings. Indoor radon concentrations were aggregated according to geologic units and hydrogeologic settings in Pennsylvania to produce maps displaying areas of the State where median radon concentrations exceeded the USEPA action level of $4 \mathrm{pCi} / \mathrm{L}$. Concentration data are characterized using a simple descriptive approach, in terms of the quartiles of measured values, and summary statistics (quartiles, skewness) for indoor radon concentrations are listed in tables.

\section{Study Area}

The State of Pennsylvania encompasses approximately 45,307 square miles and includes parts of seven major physiographic provinces: Atlantic Coastal Plain, Piedmont, New England, Blue Ridge, Ridge and Valley, Appalachian Plateaus, and Central Lowlands. In some areas, the Appalachian Plateaus and Central Lowlands are overlain by unconsolidated material (Soller and Packard, 1998), such as sand and gravel. Elevation of the land surface ranges from sea level in the Atlantic Coastal Plain province to 3,641 feet above the North American Vertical Datum of 1988 (NAVD 88) in the Appalachian Plateaus province (Gesch, 2007; Gesch and others, 2002).

\section{Land Use and Population}

Land use in Pennsylvania is about 63 percent forested (forest, shrub, grasslands, wetlands), 25 percent agricultural (pasture, cultivated crops), and 11 percent urban (developed, barren land) (fig. 1) (LaMotte, 2008). Forested land use is found primarily on ridge tops throughout the central part of the State and in the north-central tier. Agricultural land use is concentrated in valleys throughout the central and southeastern parts of Pennsylvania. Urban land use is mainly concentrated in the southeastern part of the State (fig. 1). Most cities with populations greater than 40,000 are located in eastern Pennsylvania (figs. 1 and 2). Cities with populations greater than 40,000 are Philadelphia with a population of $1,526,006$; Pittsburgh, 305,704; Allentown, 118,032; Erie, 101,786; Reading, 88,082; Scranton, 76,089; Bethlehem, 74,982; Lancaster, 59,322; Harrisburg, 49,528; Altoona, 46,320; York, 43,718; and Wilkes-Barre, 41,498 (U.S. Bureau of the Census, 2010) (figs. 1 and 2). The locations of these cities correspond to those areas of the State with the highest population densities (greater than or equal to 25,001 people per square mile) (fig. 2). The north-central and south-central parts of Pennsylvania have large areas with the lowest population densities (less than or equal to 25 people per square mile) (fig. 2). 


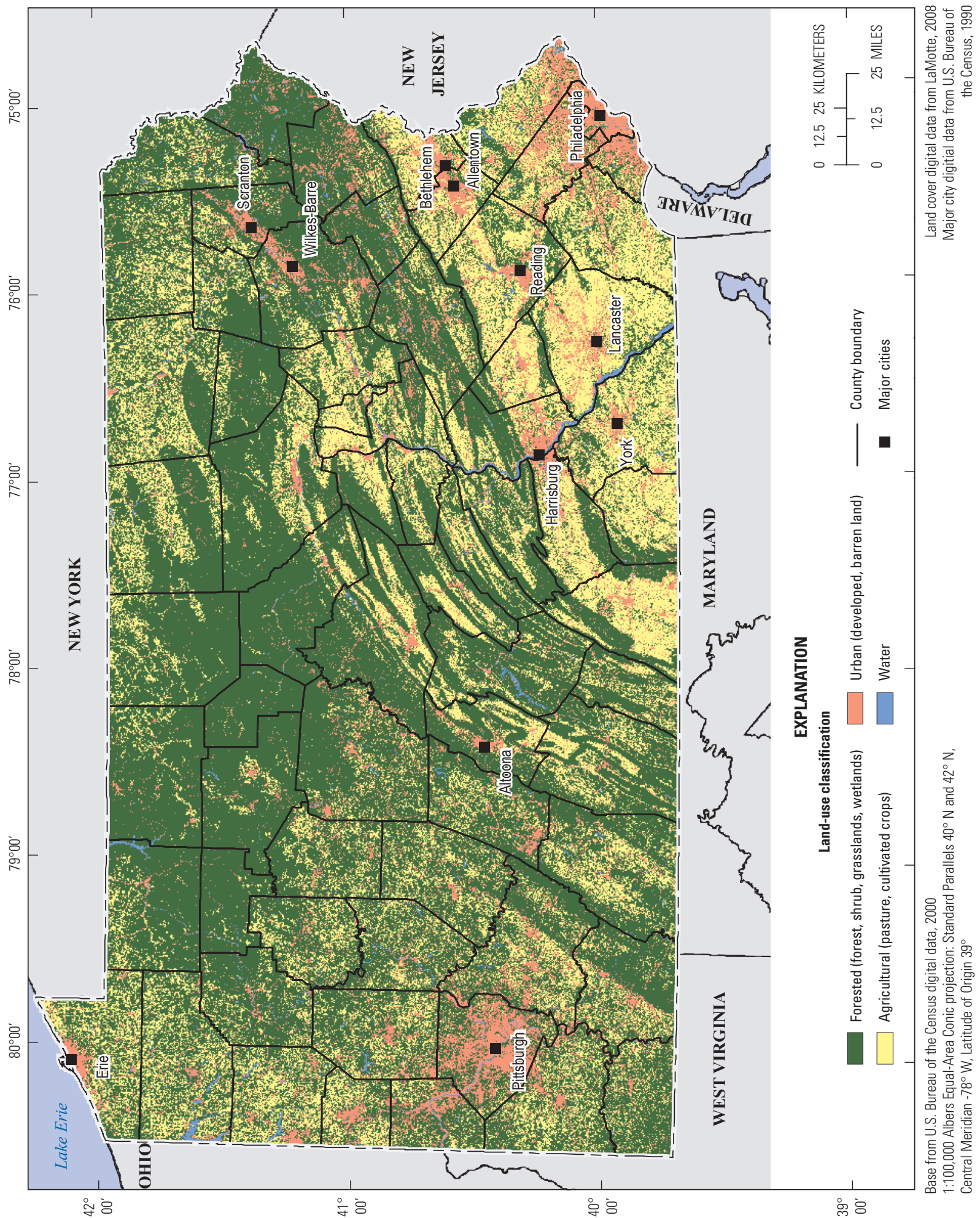




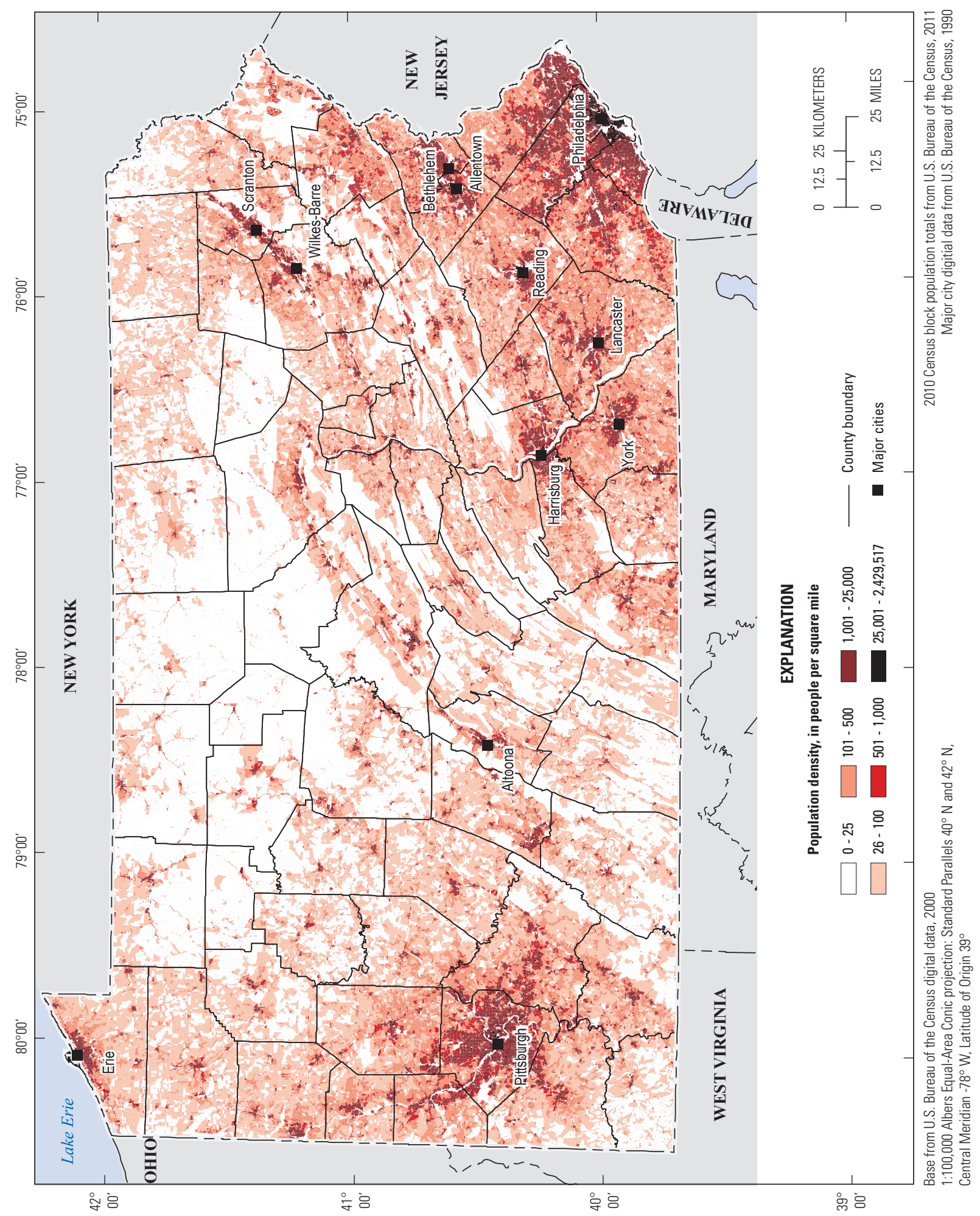




\section{Hydrogeologic Settings}

The Pennsylvania Geological Survey recognizes 193 geologic units throughout the State (Pennsylvania Geological Survey, 2001). These geologic units were allocated to different hydrogeologic settings according to physiographic provinces and major aquifer types (carbonate, crystalline, siliciclastic, and surficial) by Lindsey and Bickford (1999) to define 20 hydrogeologic settings (fig. 3). Hydrogeologic settings are used in this report to assess and describe indoor radon occurrence on a broader scale than individual geologic units.

Hydrogeologic settings with carbonate aquifers-Appalachian Mountain, Devonian-Silurian, Great Valley, and Piedmont - consist mainly of limestone and dolomite. Those hydrogeologic settings with crystalline aquifers-Blue Ridge, Piedmont, and Reading Prong - are composed mostly of igneous and metamorphic rock. Hydrogeologic settings with siliciclastic aquifers are mainly composed of sandstone, siltstone, conglomerate, and shale; these settings are the Allegheny Mountain, Appalachian Mountain, Appalachian Plateaus Forested, Glaciated Low Plateau, Glaciated Pittsburgh Plateau, Great Valley, Pittsburgh Low Plateau, and Triassic Lowland. Hydrogeologic settings with surficial aquifers are composed of unconsolidated material, such as sand and gravel; these settings are the Allegheny-Monongahela Terraces, Atlantic Coastal Plain, Eastern Lake, Northeastern Glaciated Aquifers, and Northwestern Glaciated Aquifers.

\section{Previous Studies}

Indoor radon occurrence and its relation to geology and other environmental factors have been previously studied in Pennsylvania and surrounding areas. In 1980, Smith and Barnes (Pennsylvania Geological Survey, written commun., 1980) collected samples during a detailed study of the Reading Prong hydrogeologic setting (fig. 3) to analyze the geology and mineralogy of uranium and thorium in the area. This study enabled the Pennsylvania Geological Survey (PAGS) to pinpoint specific rock types, soils, and geologic units within the Reading Prong with high uranium content that could, in turn, create indoor radon problems in homes.

Sachs and others (1982) examined the spatial variability of radon concentrations in houses in eastern Pennsylvania and the variability of geological factors, such as bedrock type, uranium concentrations in groundwater, and radon emanation from soils, as indicators of potential radon sources in an attempt to predict where indoor radon concentrations are likely to be highest. They concluded that geological factors are likely to be the predominant causes of high indoor radon concentrations. They also concluded that, although there is poor predictability in using geological factors to predict high concentrations on a building-by-building basis because variability among unique house construction and ventilation factors cannot be constrained, knowledge of underlying geology can be useful for predicting locations of high indoor radon concentrations within a region once areas of high concentrations are identified.

In a 1993 study, Gunderson (1993) concluded that bedrock geologic models for indoor radon, which include geologic parameters, soil radon data, and gamma-ray measurement data (fig. 4), could be used successfully to predict radon occurrence and concentrations in the eastern United States. Bedrock and soil properties (for example, porosity, permeability, moisture content, and clay content) are important radon indicators because bedrock and soils can contain uranium and (or) radium, from which radon is derived, and are capable of inhibiting or facilitating the movement of radon gas. Surficial gamma-ray measurement data (fig. 4) are also important potential radon indicators because they provide an estimate of uranium and radium concentrations in bedrock outcrop, soil, and surficial deposits. Gunderson (1991) estimated concentrations of uranium in soils and bedrock and identified faults and shear zones as sites of localized uranium concentrations. Faults and shear zones have been associated with some of the highest reported indoor radon concentrations.

In 1993, the USGS partnered with the USEPA to compile a series of geologic radon potential assessments for the United States, which resulted in a nationwide map of radon zones, with Zone 1 having the highest radon potential and Zone 3 having the lowest radon potential. (The data are available at $h t t p: / / w w w . e p a . g o v /$ radon/pdfs/zonemapcolor.pdf; U.S. Environmental Protection Agency, 1993). The country was divided according to the 10 USEPA regions, and the geologic radon potential was assessed within each region and extrapolated to counties so that each county could be assigned to a zone. As part of the study assessing geologic radon potential in region 3, which includes Delaware, Maryland, Pennsylvania, Virginia, and West Virginia, Gunderson and Smoot (1993) performed a detailed analysis of data on geology, radioactivity, and indoor radon in Pennsylvania. Gunderson and Smoot (1993) concluded that many of the soils, surficial deposits, and rocks in the State have the potential to generate indoor radon concentrations greater than $4 \mathrm{pCi} / \mathrm{L}$. They classified rocks, soils, and surficial deposits across the State as having (1) low, (2) variable or moderate, or (3) high radon potential (fig. 5). The Atlantic Coastal Plain, southwestern part of the Triassic Lowland, and Blue Ridge hydrogeologic settings were identified as having low radon potential. The Allegheny Mountain, Glaciated Pittsburgh Plateau, northeastern part of the Triassic Lowland, eastern parts of the Appalachian Plateaus Forested, and parts of the Pittsburgh Low Plateau (fig. 3) were identified as having variable or moderate radon potential. The Reading Prong, Piedmont, northeastern part of the Triassic Lowland, Great Valley, and Appalachian Mountain hydrogeologic settings were identified as having high radon potential. 


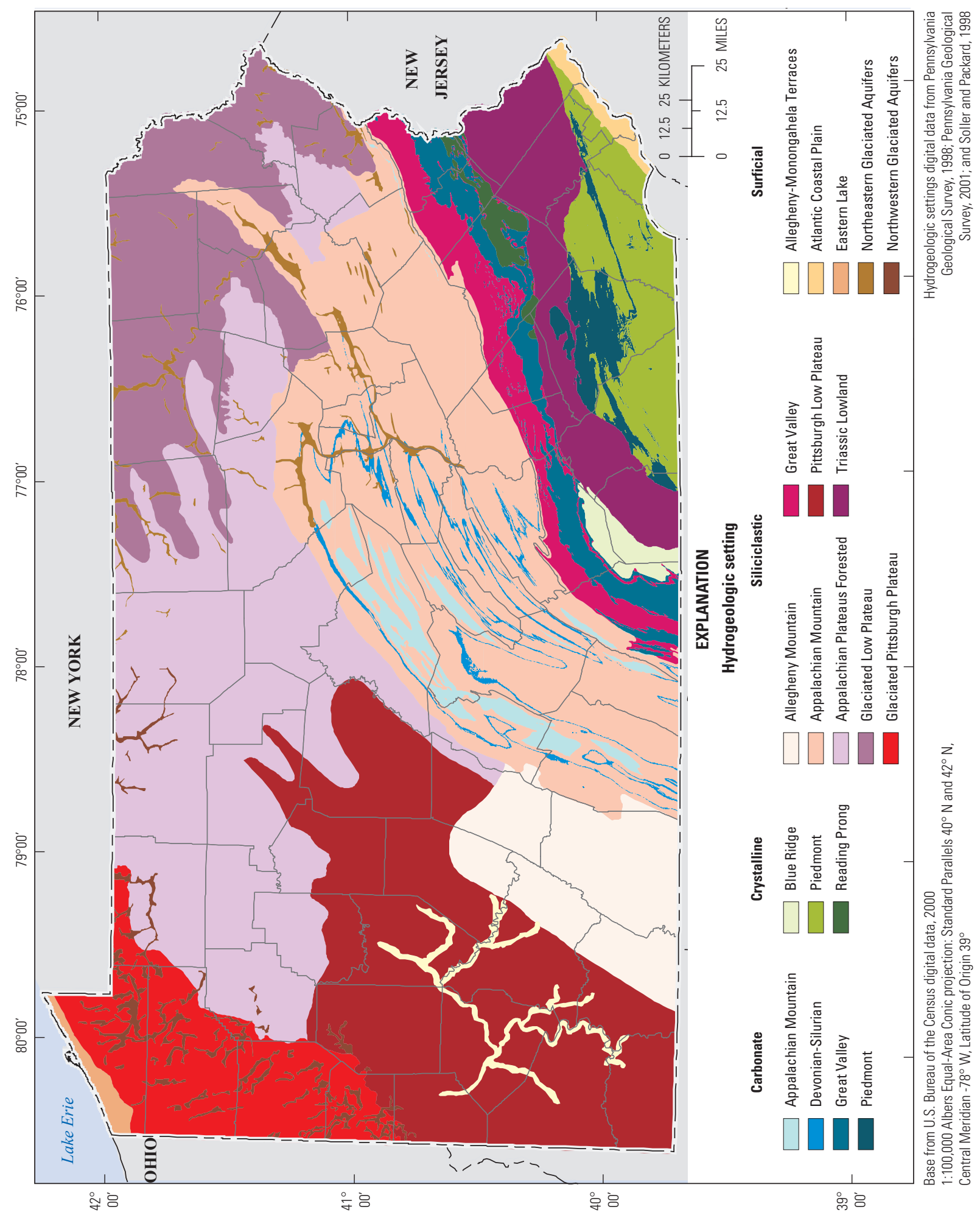




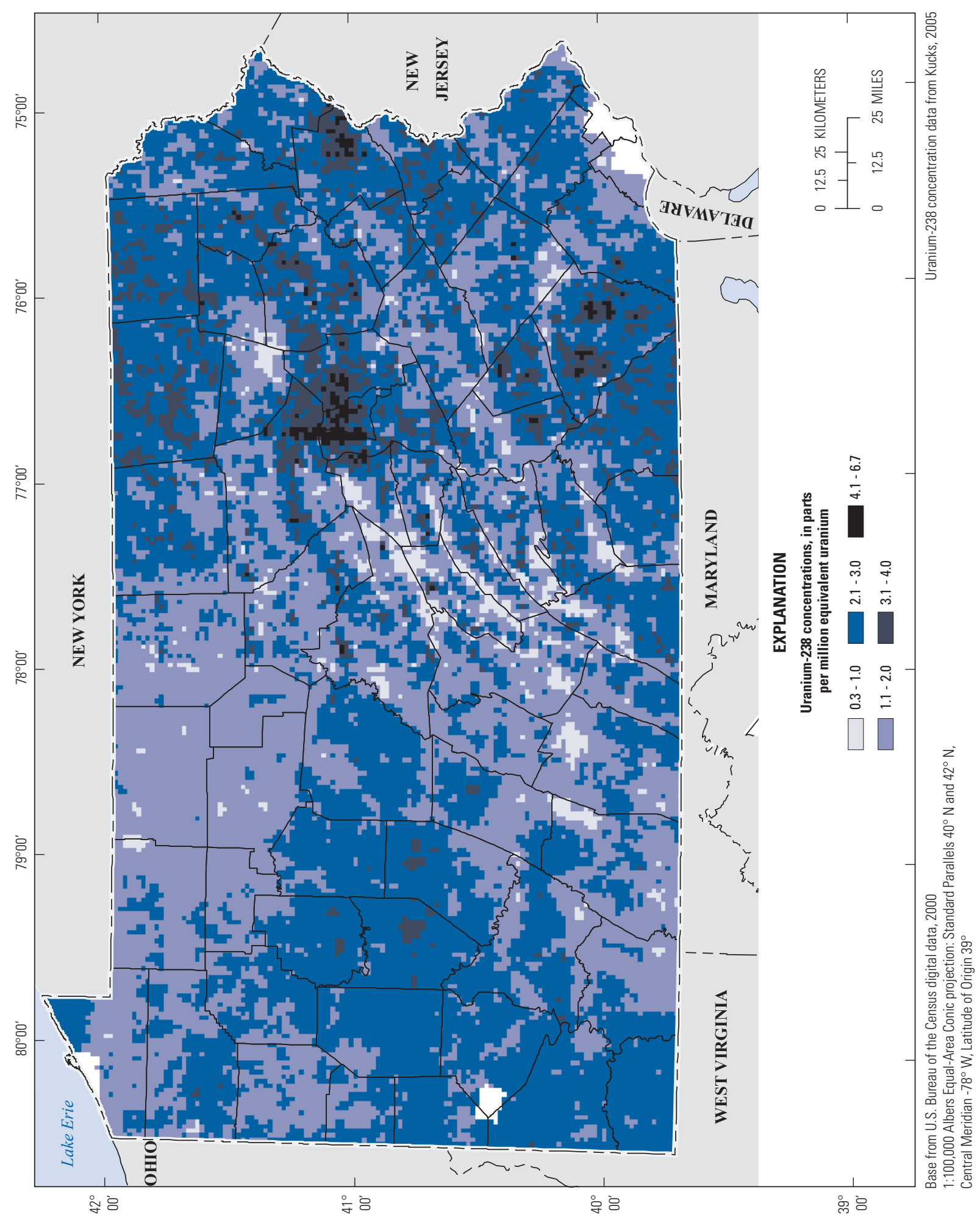




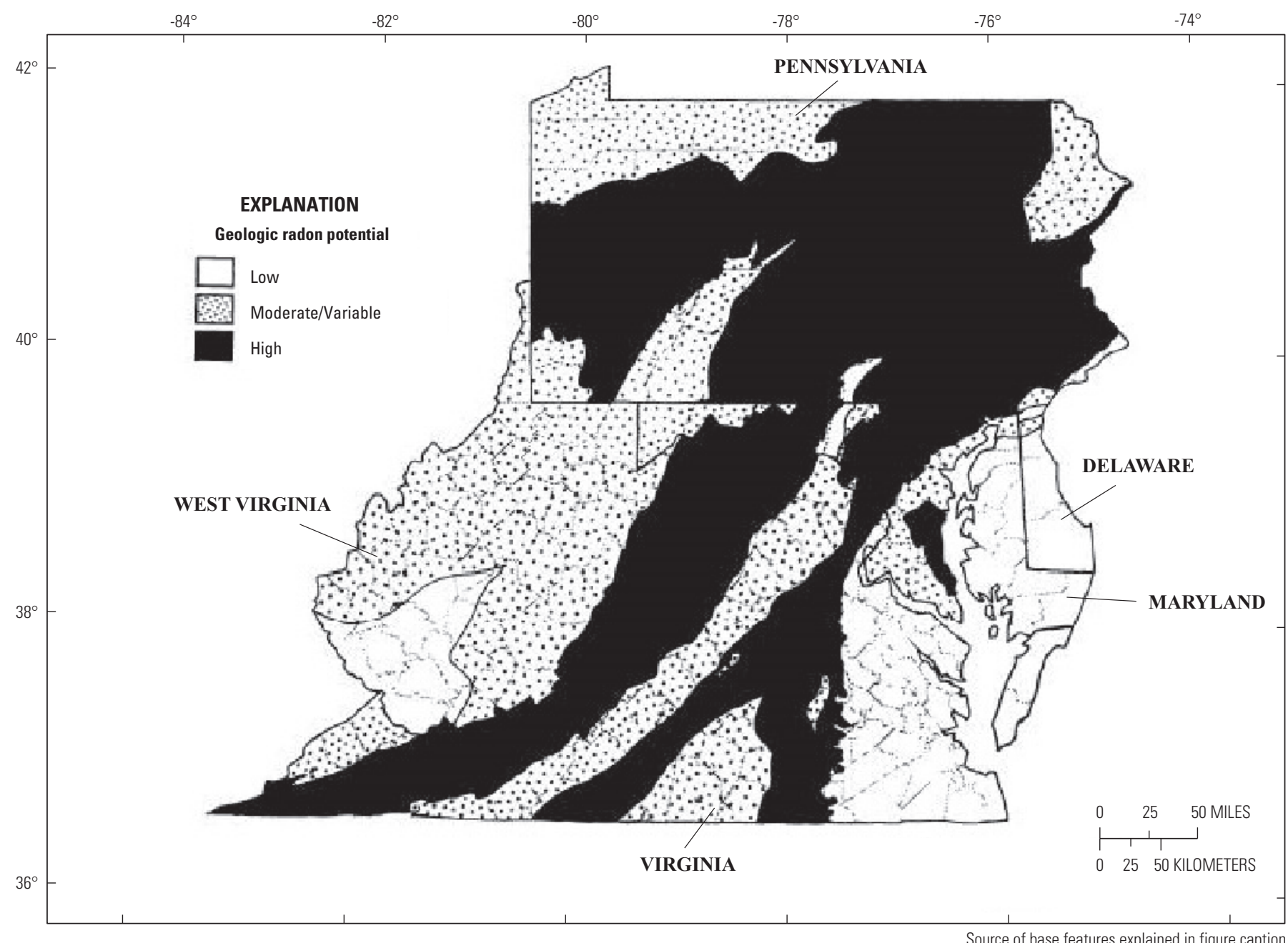

Figure 5. Geologic radon potential for U.S. Environmental Protection Agency, Region 3, adapted from Gunderson and Smoot, 1993.

\section{Indoor Radon Concentration Data}

Indoor radon concentration data were obtained from a database compiled by the PADEP, Bureau of Radiation Protection, Radon Division. The indoor radon concentration data are the results from indoor radon tests conducted in Pennsylvania from 1990 to 2007 and submitted to the PADEP by certified laboratories and testers. Most of the radon testing occurred during real estate transactions. The original data obtained from the PADEP contained 878,160 records with associated attribute information including county, municipality, zip code, spatial coordinates geocoded from address, geocoding precision score, house type (ranch, trailer, apartment), date (begin and end), test length (duration), test result, testing method (type of monitor used), and testing location (basement, first floor, second floor, and so forth). Source of water to the home was not recorded, which is a potential limitation because in homes that receive drinking water from a private well or public water supplier accessing groundwater containing dissolved radon, the radon gas will escape from drinking water and accumulate in the air when it is used for showering and other household uses.

For the purposes of analyses presented in this report, the original dataset was edited to include only records with geocoding precision scores equal to 100 (scores can range from 0 to 100 and are a measure of confidence of geocoding precision, but even scores equal to 100 can still be inaccurate by as much as 700 feet), basement testing locations, shortterm test results (results from tests lasting less than or equal to 90 days), and test results that were greater than or equal to zero to remove test results that did not have a value. Numerical values of test results were otherwise reported as obtained from the PADEP. Also, a geographic information system (GIS) was used to remove those records with spatial coordinates that did not fall within the Pennsylvania Geological Survey's bedrock geology dataset (Pennsylvania Geological Survey, 2001) because this dataset is used for most analyses. After all edits were completed, the final dataset contained 548,507 test results with indoor radon concentrations. 


\section{Distribution of Indoor Radon Concentrations}

This section of the report documents the distribution of indoor radon concentrations in Pennsylvania, 1990-2007. The distribution of indoor radon concentrations was analyzed statewide, and the data were aggregated and analyzed according to geologic units and hydrogeologic settings. Spatial distribution was defined using the quartiles of measured population distribution. Analysis using the lognormal distribution of the data, which can be used to focus analysis on the high concentrations in a measured population of data (for example, the upper quartile), was not conducted in this study.

The frequency distribution of 548,507 indoor radon concentrations in Pennsylvania is shown in figure 6. The median concentration was 3.0 picocuries per liter $(\mathrm{pCi} / \mathrm{L})$; the minimum and maximum concentrations were $0.0 \mathrm{pCi} / \mathrm{L}$ (set by data censoring) and $1,866.4 \mathrm{pCi} / \mathrm{L}$, respectively. About 39 percent $(215,138)$ of test results had indoor radon concentrations greater than or equal to the USEPA action level of $4 \mathrm{pCi} / \mathrm{L}$.

The density of indoor radon test results is shown in figure 7 according to geologic unit to show the spatial distribution of test result locations. In most areas, the test results had a wide range of indoor radon concentrations. For the most part, test result locations are in urban and suburban areas across the State, which are mainly in and around the Philadelphia and Pittsburgh areas, because this is where most of the population within the State resides.

\section{Indoor Radon Concentrations According to Geologic Unit}

Indoor radon test results were analyzed according to 193 geologic units in Pennsylvania to determine general patterns of indoor radon concentrations among the units. Of the State's 193 geologic units, 5 units had no corresponding indoor radon concentration data. Concentrations of indoor radon in most of the geologic units were highly variable, so the units were classified on the basis of median indoor radon concentration, which is the concentration at which one-half of the samples have a lower concentration and one-half have a higher concentration. For data analysis, a median radon concentration of $4 \mathrm{pCi} / \mathrm{L}$ was chosen as a boundary value for grouping geologic units and hydrogeologic settings because the USEPA recommends fixing the home if the radon concentration is equal to or greater than $4 \mathrm{pCi} / \mathrm{L}$. The degree of skewness is commonly high (table 1, back of report) and indicates that, for many geologic units, additional information might be gained from computing lognormal distributions and focusing additional analysis on the high-concentration data.

When analyzed according to Pennsylvania's geologic units, 93 of 188 (49.5 percent) geologic units with indoor radon concentrations had median concentrations greater than or equal to the USEPA action level of $4 \mathrm{pCi} / \mathrm{L}$ (table 1), likely

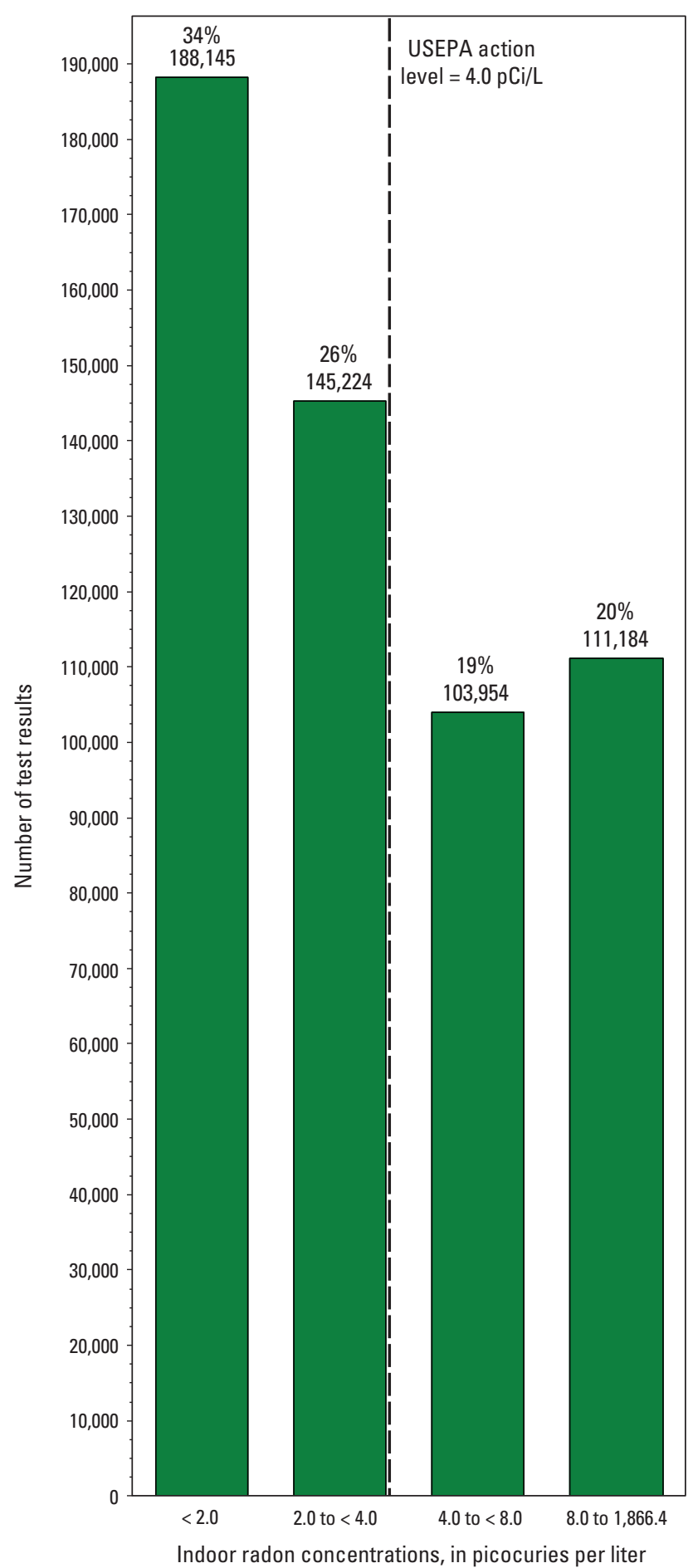

Figure 6. Frequency of indoor radon concentrations from tests from a database compiled by the Pennsylvania Department of Environmental Protection, Bureau of Radiation Protection, Radon Division. (USEPA, U.S. Environmental Protection Agency; pCi/L, picocuries per liter; \%, percent of tests; $<$, less than) 


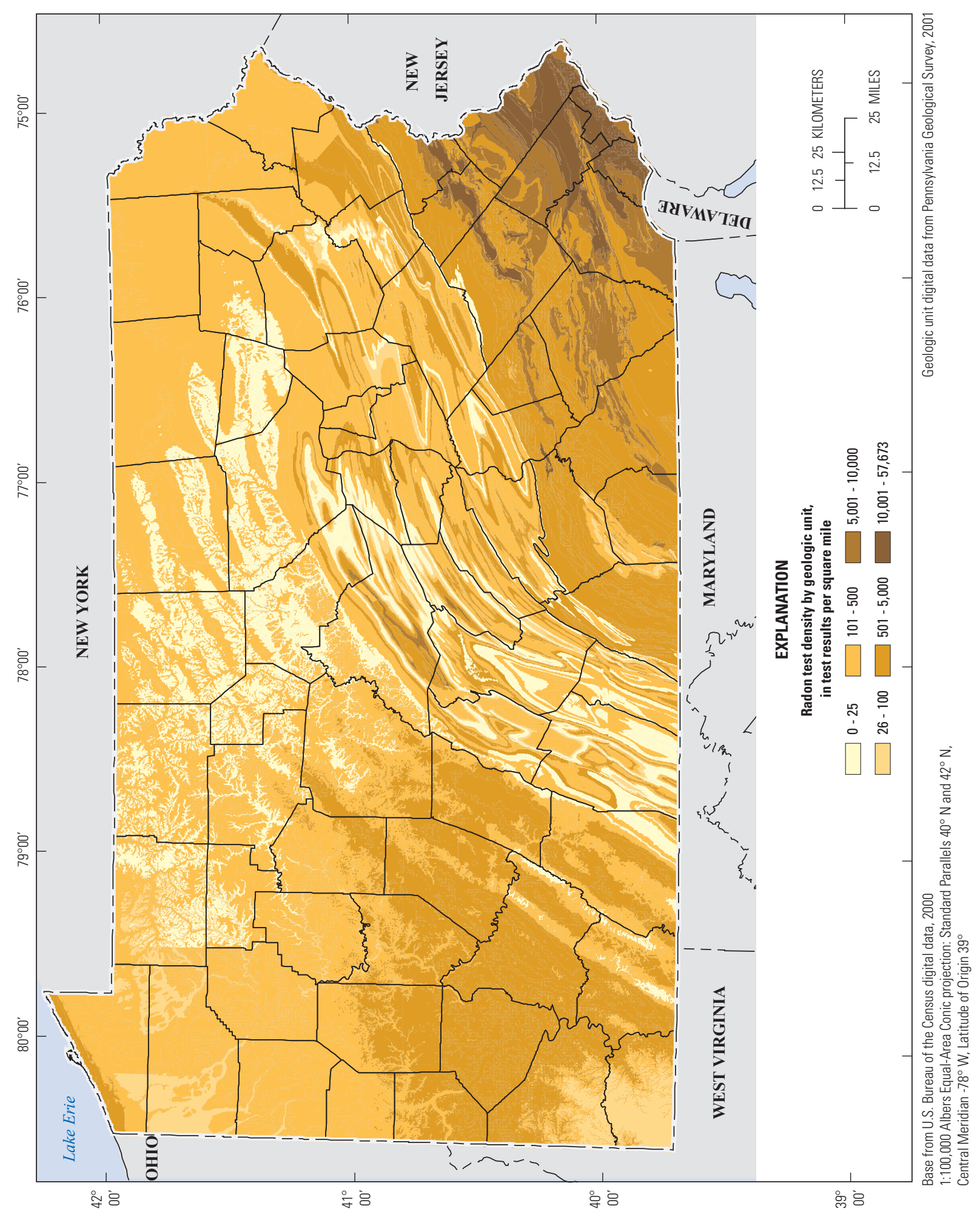

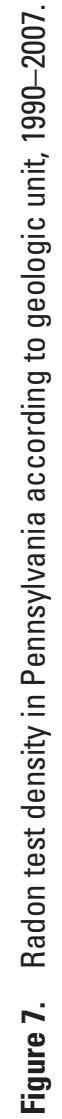


representing the bulk of the 39 percent of test results greater than or equal to $4 \mathrm{pCi} / \mathrm{L}$. Geologic units with median indoor radon concentrations greater than or equal to $4 \mathrm{pCi} / \mathrm{L}$ are shaded red in figure 8 . Most of these units are located in the eastern part of the State. Many of these units are well represented by the dataset, but some are not. Thin units in complex crystalline and carbonate terranes are least likely to be represented adequately. For example, the Wakefield Marble (crystalline Piedmont hydrogeologic setting), which had the highest median indoor radon concentration of $57.9 \mathrm{pCi} / \mathrm{L}$, had only two test results. The geologic unit with the most test results $(47,897)$ was the Stockton Formation (siliciclastic Triassic Lowland hydrogeologic setting) with a median indoor radon concentration of $2.4 \mathrm{pCi} / \mathrm{L}$. The geologic unit with the highest number of test results and median indoor radon concentration greater than or equal to 4 was the Octoraro Formation (crystalline Piedmont hydrogeologic setting) with 13,787 test results and a median concentration of $4.1 \mathrm{pCi} / \mathrm{L}$. The highest indoor radon concentration from a single test result $(1,866.4 \mathrm{pCi} / \mathrm{L})$ was measured in an area of Lower Cambrian rocks (carbonate Great Valley hydrogeologic setting). A total of 920 test results were obtained for this unit; the median concentration was $6.1 \mathrm{pCi} / \mathrm{L}$. The geologic unit with the lowest median indoor radon concentration $(0.6 \mathrm{pCi} / \mathrm{L})$ was the Shawangunk Formation (siliciclastic Appalachian Mountain hydrogeologic setting); nine test results were available for this unit.

\section{Indoor Radon Concentrations According to Hydrogeologic Setting}

Because indoor radon test results were not available for all 193 geologic units and the number of test results per unit varied widely for those units that had results (1 to 47,897), median indoor radon concentrations were further aggregated and analyzed according to 20 hydrogeologic settings (table 2). As was apparent for the geologic units, the degree of skewness is commonly high (table 2 ) for the hydrogeologic settings and indicates that additional information might be gained from computing lognormal distributions. The crystalline Blue Ridge hydrogeologic setting contained the lowest number of test results (535), whereas the Siliciclastic Triassic Lowland contained the highest number of test results $(119,389)$.

Hydrogeologic settings with median indoor radon concentrations greater than the USEPA action level of $4 \mathrm{pCi} / \mathrm{L}$ are shaded red in figure 9; these include 5 of the 20 settings: carbonate Appalachian Mountain $(6.3 \mathrm{pCi} / \mathrm{L})$, siliciclastic Great Valley $(6.0 \mathrm{pCi} / \mathrm{L})$, carbonate Great Valley $(5.0 \mathrm{pCi} / \mathrm{L})$, crystalline Reading Prong $(4.8 \mathrm{pCi} / \mathrm{L})$, and carbonate Devonian-Silurian $(4.1 \mathrm{pCi} / \mathrm{L})$. These hydrogeologic settings are located mostly in the south-central part of the State. Three of the hydrogeologic settings with median indoor radon concentrations greater than the USEPA action level of $4 \mathrm{pCi} / \mathrm{L}$ are carbonate hydrogeologic settings. This is consistent with findings reported by previously conducted studies. Smith (1978) describes faulted shear zones within the Reading Prong hydrogeologic setting that are known to contain crystalline rocks that are uranium-rich. Also, Gunderson and Smoot (1993) discuss how the dissolution of carbonate rocks creates soils that are enriched in impurities, including radionuclides such as uranium and radium. Greeman and Rose (1990) found that soils developed on carbonate rocks in central Pennsylvania exhibited radon emanation almost entirely attributed to highly emanative radium bound in soil organic matter. This pattern of radon-rich soil developing from uranium-rich strata, such as carbonate bedrock, has also been studied in West Virginia (Brower and others, 1991; Schultz and others, 1992). When comparing figures 8 and 9 to figure 4, it is apparent that the geologic units and hydrogeologic settings with the highest median indoor radon concentrations seem to correspond with those parts of the State with the highest uranium concentrations as measured by the aerial gamma-ray survey. Therefore, crystalline rocks and soils developed from carbonate rocks can have high uranium and radium contents and soil-gas radon concentrations, which can lead to high indoor radon concentrations (Gunderson and Smoot, 1993; Greeman and Rose, 1990). The black shales of the siliciclastic Great Valley are also cited in Gunderson and Smoot (1993) as having uranium content higher than other rock types and being effective emanators of radon (Gunderson and Smoot, 1993). Also, Gunderson (1991) discusses how shear zones within the Reading Prong rocks enhance the uranium content and radon potential of these rocks and create local occurrences of high uranium and indoor radon concentrations (Gunderson, 1991).

The surficial Atlantic Coastal Plain hydrogeologic setting had the lowest median indoor radon concentration $(1.6 \mathrm{pCi} / \mathrm{L})$ and was the only hydrogeologic setting with a median indoor radon concentration less than $2 \mathrm{pCi} / \mathrm{L}$, which is the concentration above which the USEPA recommends that homeowners consider mitigation of radon. This low frequency of occurrence of high radon values is consistent with the findings of Gunderson and Smoot (1993), who state that the sediments, soils, and surficial deposits of the Atlantic Coastal Plain, in general, have low radon potential (Gunderson and Smoot, 1993). 


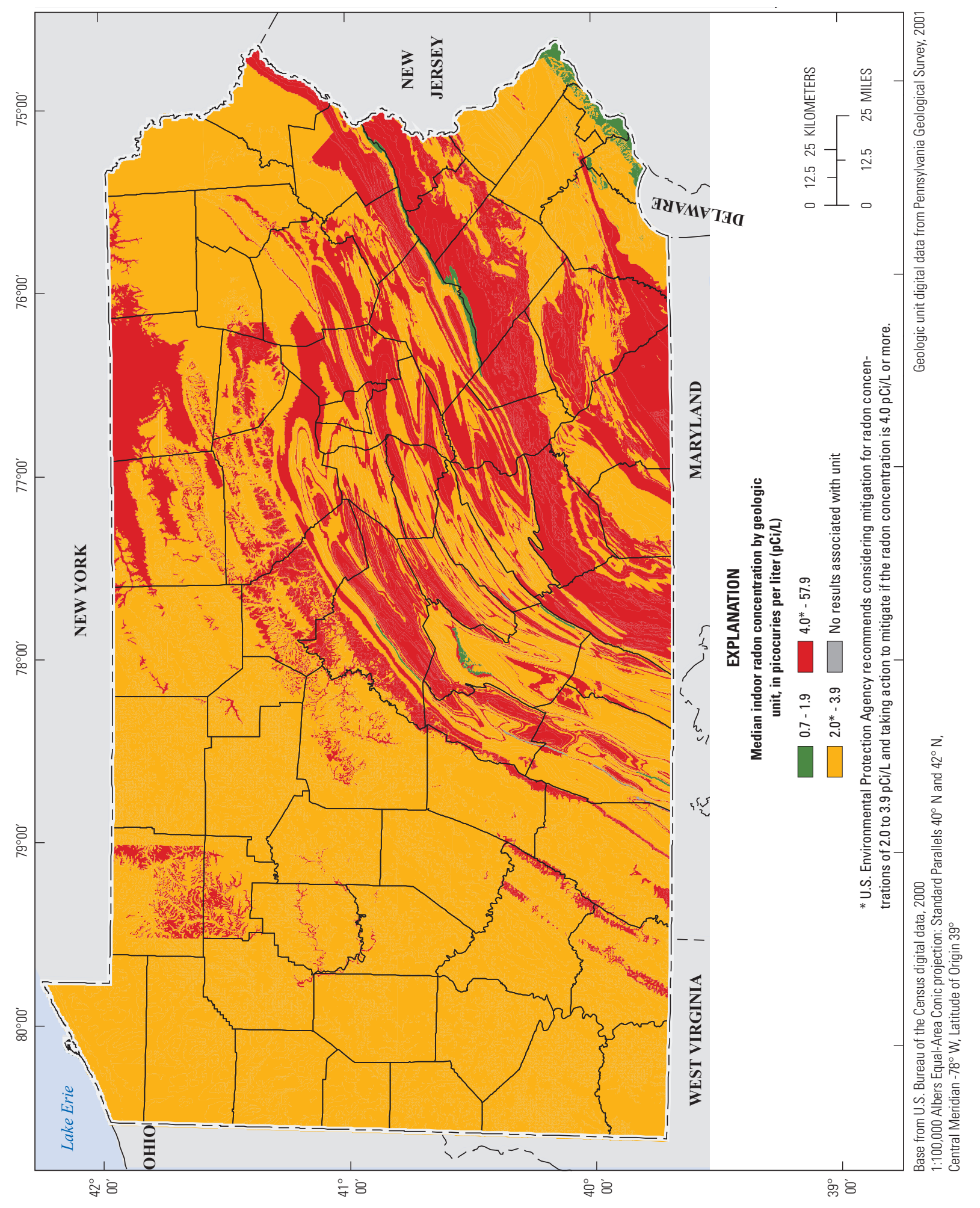

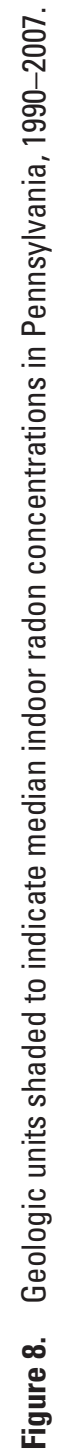




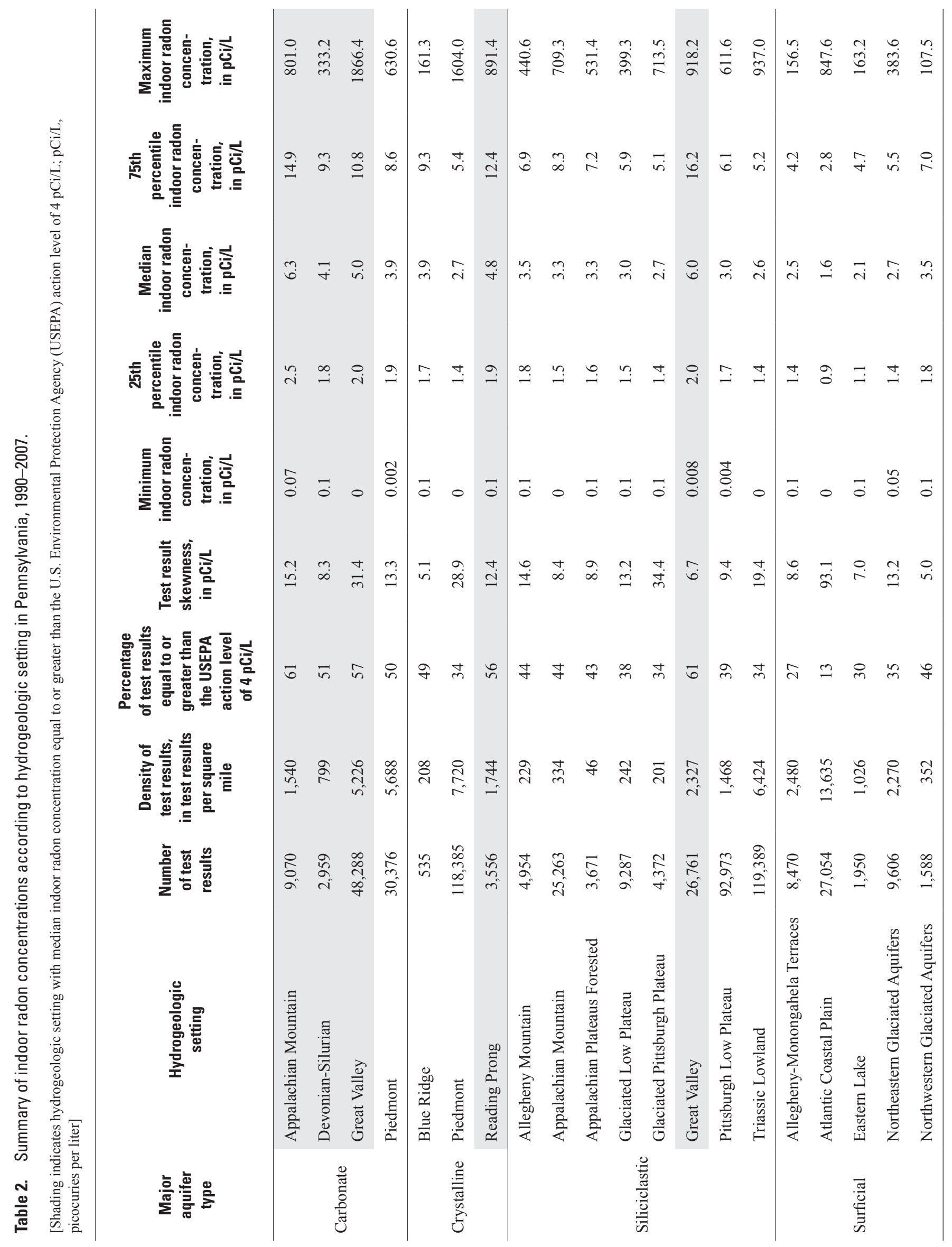




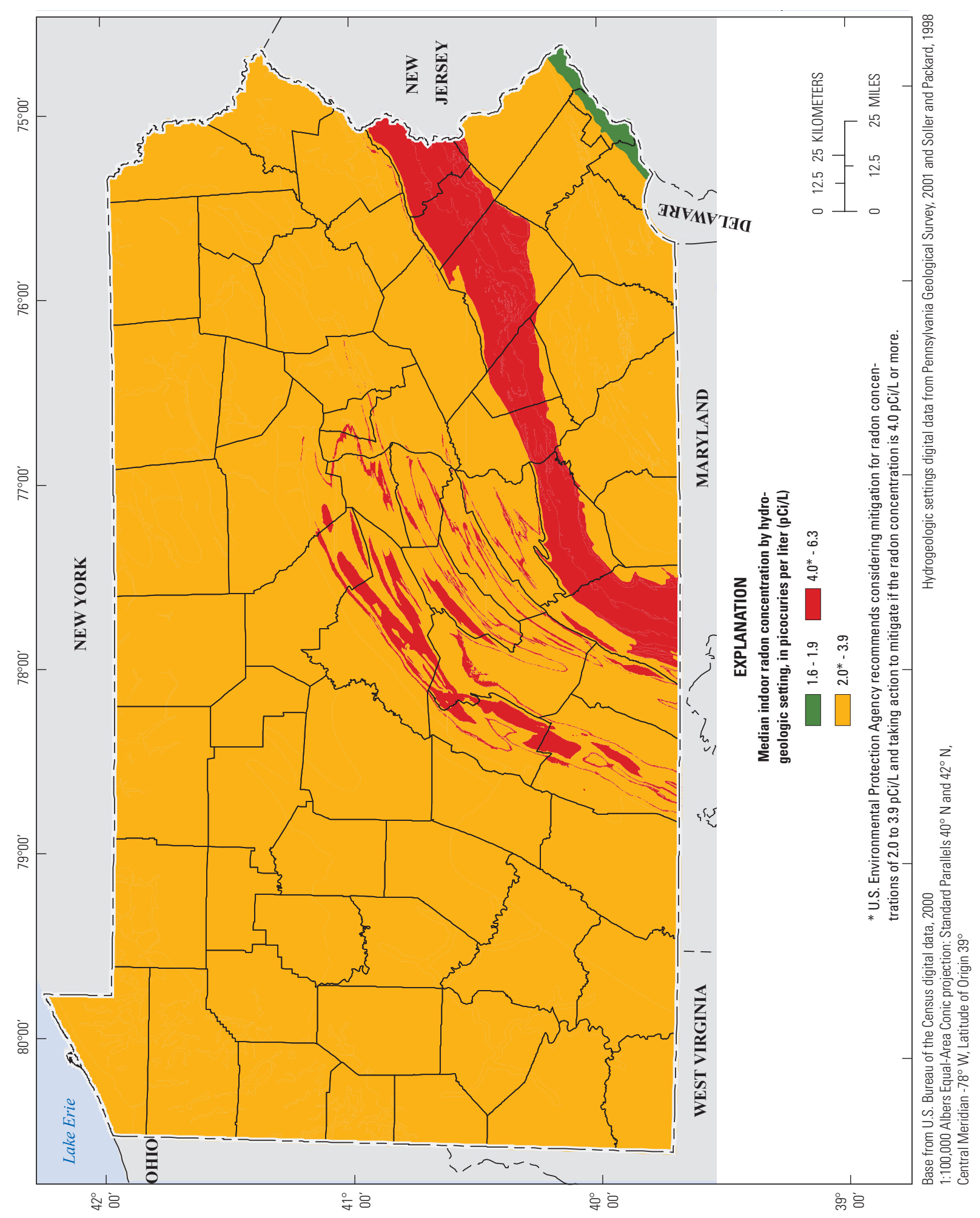

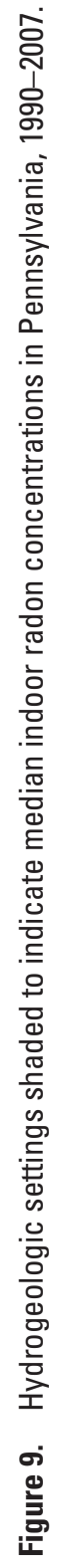




\section{Uses and Limitations of Aggregated Radon Data}

Aggregated radon data presented for Pennsylvania in the present study (figs. 8 and 9) indicate that most of Pennsylvania contains geologic units and hydrogeologic settings with median indoor radon concentrations greater than or equal to $2 \mathrm{pCi} / \mathrm{L}$ (the concentrations at which the USEPA recommends that property owners consider remediating homes or buildings) and less than $4 \mathrm{pCi} / \mathrm{L}$ (the concentration at which the USEPA recommends that property owners remediate homes or buildings). It is important to note that median concentrations of indoor radon are useful for drawing general conclusions about the occurrence of indoor radon in specific geologic units and hydrogeologic settings, but these concentration distributions are not proposed for use in predicting individual concentrations at specific sites nor for use as a decision-making tool for property owners to decide whether to test for indoor radon concentrations at specific property locations. Maps showing median indoor radon test results aggregated according to geologic unit and hydrogeologic setting in Pennsylvania (figs. 8 and 9) also indicate that the areas with high radon risk potential can be better and more narrowly defined than areas delineated at the national scale or on the basis of county, as has been done previously (http://www.epa.gov/ radon/pdfs/zonemapcolor.pdf; U.S. Environmental Protection Agency, 1993).

Interpretations of the aggregated radon data may be affected in some cases by limitations of the data. For example, there is no information in the dataset about whether any test results were conducted after high radon concentrations in the tested building were identified and remediated. This could affect interpretations of the data in the Reading Prong hydrogeologic setting, where a large amount of data were collected prior to 1990. Data included in this study are from 1990 and later, so much of the test-result data from the Reading Prong hydrogeologic setting that are used in this report could represent post-remediation conditions or follow-up test results.

Another potential limitation of the data interpretation results from the uneven or inaccurate distribution of the data among geologic units. Some geologic units have inadequate sample distribution. For example, thin units in complex crystalline and carbonate terranes are the least likely to be represented adequately. In contrast, some geologic units have clusterings of test results and are over-represented. Geocoding scores, even with confidence scores of 100 out of 100 , could be off as much as 700 feet, so some test results may be grouped into geologic units or hydrogeologic settings that they do not represent, and this would be especially true for small, thin geologic units. In addition, there is inherent error in the original geologic unit dataset created by the Pennsylvania Geological Survey (2001) because the dataset is accurate at a 1:250,000 scale and it represents a broad interpretation of geologic units across the State. More precise mapping designed to minimize interfering biases and maximize geological factors is desirable for improved maps (Miles, 1998). Finally, some geologic units and (or) hydrogeologic settings might be better represented if they were separated into several units and (or) settings and listed in two categories of severity. For example, the Triassic Lowland hydrogeologic setting could be divided into the Gettysburg Basin and Newark Basin; with this approach, the potential risk associated with high radon concentrations in the Triassic Lowland hydrogeologic setting might be more accurately represented because one basin may have significantly higher radon test results than the other.

The maps derived from the indoor radon concentration data can be used as tools for resource decision-making and may also have value for ecological-level analysis of disease outcomes. These maps are intended to be available through databases of the Centers for Disease Control and the Pennsylvania Environmental Public Health Tracking programs that are available on the Internet. For further information regarding radon in Pennsylvania, visit the Pennsylvania Department of Environmental Protection Radon Website at www.depweb. state.pa.us (keyword: Radon) or call the PADEP Radon Hotline at 1-800-237-2366 or the PADEP Radon Division at $717-783-3594$.

\section{Summary and Conclusions}

The distribution of indoor radon concentrations was evaluated for 548,507 test results collected from 1990 to 2007 throughout Pennsylvania. Indoor radon concentrations greater than or equal to the U.S. Environmental Protection Agency (USEPA) action level of 4 picocuries per liter ( $\mathrm{pCi} / \mathrm{L}$ ) were observed for 39 percent of the test results. The highest test result was a concentration of $1,866.4 \mathrm{pCi} / \mathrm{L}$.

Indoor radon concentrations were aggregated according to geologic units and hydrogeologic settings for spatial analysis. When analyzed according to Pennsylvania's geologic units, the median concentration for 93 of 188 (49.5 percent) geologic units with indoor radon concentrations was greater than the USEPA action level of $4 \mathrm{pCi} / \mathrm{L}$; most of these geologic units are located in the eastern part of the State. When analyzed according to Pennsylvania's hydrogeologic settings, the median concentrations for 5 of the 20 ( 25 percent) settings were greater than the USEPA action level of $4 \mathrm{pCi} / \mathrm{L}$; these settings are the carbonate Appalachian Mountain $(6.3 \mathrm{pCi} / \mathrm{L})$, siliciclastic Great Valley (6.0 pCi/L), carbonate Great Valley $(5.0 \mathrm{pCi} / \mathrm{L})$, crystalline Reading Prong $(4.8 \mathrm{pCi} / \mathrm{L})$, and carbonate Devonian-Silurian $(4.1 \mathrm{pCi} / \mathrm{L})$. The surficial Atlantic Coastal Plain hydrogeologic setting had the lowest median indoor radon concentration $(1.6 \mathrm{pCi} / \mathrm{L})$.

Median indoor radon concentrations aggregated according to geologic units and hydrogeologic settings are useful for drawing general conclusions about the occurrence of indoor radon in specific geologic units and hydrogeologic settings, but these concentration distributions are not proposed for use in predicting individual concentrations at specific sites 
nor for use as a decision-making tool for property-owners to decide whether to test for indoor radon concentrations at specific property locations. The aggregated indoor radon data have testing and spatial accuracy limitations that potentially result from the lack of available information about testing conditions and the imprecision of geocoded test locations; whereas the associated geologic unit and hydrogeologic settings data have spatial and interpretation accuracy limitations that potentially result when statewide data are used to define conditions at test locations and heterogeneous geologic units are broadly defined.

\section{References Cited}

Brower, S.D., Rauch, H.W., and Schultz, A.P., 1991, Distribution of radon gas in ground water, soil gas and indoor air for the Great Valley of West Virginia: Geological Society of America Abstracts Programs, v. 23, no. 1, p. 11.

Folger, P.F., Nyberg, Philip, Wanty, R.B., and Poeter, Eileen, 1994, Relationships between 222Rn dissolved in ground water supplies and indoor $222 \mathrm{Rn}$ concentrations in some Colorado Front Range houses: Health Physics, v. 67, p. 245-253.

Gerusky, T.M., 1987, The Pennsylvania radon story: Journal of Environmental Health, v. 49, p. 197-200.

Gesch, D.B., 2007, The National Elevation Dataset, in Maune, D., ed., Digital Elevation Model technologies and applications: The DEM Users Manual (2nd ed.): Bethesda, Maryland, American Society for Photogrammetry and Remote Sensing, p. 99-118.

Gesch, D., Oimoen, M., Greenlee, S., Nelson, C., Steuck, M., and Tyler, D., 2002, The National Elevation Dataset: Photogrammetric Engineering and Remote Sensing, v. 68, no. 1 , p. 5-11.

Greeman, D.J., and Rose, A.W., 1990, Form and behavior of radium, uranium, and thorium in Central Pennsylvania soils derived from dolomite: Geophysical Research Letters, v. 17, p. 833-836.

Gundersen, L.C.S., 1991, Radon in sheared igneous and metamorphic rocks, in Gundersen, L.C.S., and Wanty, R.B., eds., Field studies of radon in rocks, soils, and water: U.S. Geological Survey Bulletin 1971, p. 39-50.

Gundersen, L.C.S., 1993, The correlation between bedrock geology and indoor radon: Where it works and where it doesn't - some examples from the eastern United States, in The 1993 International Radon Conference, September 20-22, 1993, Denver, Colorado, Preprints, p. IV-1-IV-8.
Gundersen, L.C.S., and Smoot, J.P., 1993, Preliminary geologic radon potential assessment of Pennsylvania, in Shumann, R.R., ed., Geologic radon potential of EPA Region 3: U.S. Geological Survey Open-File Report 93-292-C, p. 105-145.

Hess, C.T., Korash, J.K., and Einloth, C.J., 1987, Radon in houses due to radon in potable water: in Hopke, P.K., ed., Radon and its decay products: Occurrence Properties and Health Effects, American Chemical Society Symposium Series 331, American Chemical Society, Washington, D.C., p. $30-41$.

Kucks, R.P., 2005, Terrestrial radioactivity and gamma-ray exposure in the United States and Canada: gridded geographic images: U.S. Geological Survey, digital data, accessed July 9, 2012, at http://pubs.usgs.gov/of/2005/1413/ datafiles.htm.

LaMotte, A., 2008, National Land Cover database 2001 (NLCD01), Tile 2, Northeast United States: NLCD01_2: U.S. Geological Survey Data Series 383B, accessed July 5, 2012, at http://water.usgs.gov/GIS/dsdl/nlcd01_2.tar.gz.

Lindsey, B.D., and Bickford, T.M., 1999, Hydrogeologic framework and sampling design for an assessment of agricultural pesticides in ground water in Pennsylvania: U.S. Geological Survey Water-Resources Investigations Report 99-4076, 44 p.

Miles, J., 1998, Mapping radon-prone areas by lognormal modeling of house radon data: Health Physics, v. 74, p. 370-378.

National Academy of Science, 1999, Health effects of exposure to radon: Biological Effects of Ionizing Radiation (BEIR) VI Report, Washington, DC: National Academy Press.

National Council on Radiation Protection and Measurements (NCRP), 1984a, Evaluation of occupational and environmental exposures to radon and radon daughters in the United States: NCRP Report 78, Bethesda, Maryland, 204 p.

National Council on Radiation Protection and Measurements (NCRP), 1984b, Exposures from the uranium series with emphasis on radon and its daughters: NCRP Report 77, Bethesda, Maryland, $131 \mathrm{p}$.

Pennsylvania Geological Survey, 2001, Bedrock geology of Pennsylvania: Pennsylvania Geological Survey, digital data, accessed June 23, 2008, at http://www.dcnr.state.pa.us/ topogeo/map1/bedmap.aspx. 
Pennsylvania Geological Survey, 1998, Preliminary Landform Subdivisions of Pennsylvania, 1998: Pennsylvania Geological Survey, digital data, accessed December 11, 2007, at ftp://www.pasda.psu.edu/pub/pasda/dcnr/pags/ pags_landform98.zip.

Sachs, H.M., Hernandez, T.L., and Ring, J.W., 1982, Regional geology and radon variability in buildings: Environment International, v. 8, p. 97-103.

Schultz, Art, Wiggs, C.R., and Brower, S.D., 1992, Geologic and environmental implications of high soil-gas radon concentrations in the Great Valley, Jefferson and Berkeley counties, West Virginia: in Gates, A.E. and Gunderson, L.C.S., eds., Geologic controls on radon, Geological Society of America Special Paper 271, p. 29-44.

Smith, II, R.C., 1978, Uranium near Oley, Berks County: Pennsylvania Geology, vol. 9, no. 4, p 29-31.

Smith, II, R.C., and Barnes, J.H., unpublished, Geology and mineralogy of uranium and thorium in the Reading Prong of Berks, Lehigh, and Northampton Counties, Pennsylvania: Pennsylvania Geological Survey, 4th ser., Mineral Resource Report 97.

Smith, II, R.C., Reilly, M.A., Rose, A.W., Barnes, J.H., and Berkheiser, S.W., April 1987, Radon: A profound case: Pennsylvania Geology, vol. 18, no. 2, p 3-7.

Soller, D.R., and Packard, P.H., 1998, Digital representation of a map showing the thickness and character of Quaternary sediments in the glaciated United States east of the Rocky Mountains: U.S. Geological Survey Digital Data Series DDS-38, 1 CD.

U.S. Bureau of the Census, 1990, City locations for all places in the TIGER files: U.S. Bureau of the Census, digital data, accessed June 11, 2008, at http://water.usgs.gov/GIS/ metadata/usgswrd/XML/places.xml.
U.S. Bureau of the Census, 2000, 2000 county \& county equivalent areas: U.S. Bureau of the Census, digital data, accessed June 11, 2008, at http://www.census.gov/geo/www/ cob/co2000.html.

U.S. Bureau of the Census, 2010, DP-1 profile of general population and housing characteristics: U.S. Bureau of the Census, table, accessed June 20, 2012, at http://factfinder2. census.gov/.

U.S. Bureau of the Census, 2011, U.S. Census TIGER/Line ${ }^{\circledR}$ Shapefiles - Tabulated Blocks: U.S. Bureau of the Census, digital data, accessed February 7, 2013, at ftp://ftp2.census. gov/geo/tiger/TIGER2010BLKPOPHU/.

U.S. Environmental Protection Agency, 1992, Consumer's guide to radon reduction-How to reduce radon levels in your home: U.S. Environmental Protection Agency, EPA 402-k92-003, 17 p.

U.S. Environmental Protection Agency, 1993, EPA's Map of Radon Zones NATIONAL SUMMARY: U.S. Environmental Protection Agency, EPA 402-R-93-071, 48 p.

U.S. Environmental Protection Agency, 2011, Why is radon the public health risk that it is?: U.S. Environmental Protection Agency, accessed November 1, 2011, at http://www. epa.gov/radon/aboutus.html.

U.S. Environmental Protection Agency, 2012, A citizen's guide to radon: U.S. Environmental Protection Agency, Indoor Environments Division, EPA402/K-12/002, 16 p., accessed June 13, 2013, at http://www.epa..gov/radon/pubs/ citguide.html.

World Health Organization, 2006, Radon and Cancer: World Health Organization, Factsheet 291, accessed February 7, 2013, at $h$ ttp://www.who.int/mediacentre/factsheets/fs 291/ en/index.html.

World Health Organization, 2009, WHO handbook on indoor radon-A public health perspective: Geneva, Switzerland, World Health Organization, 94 p. 


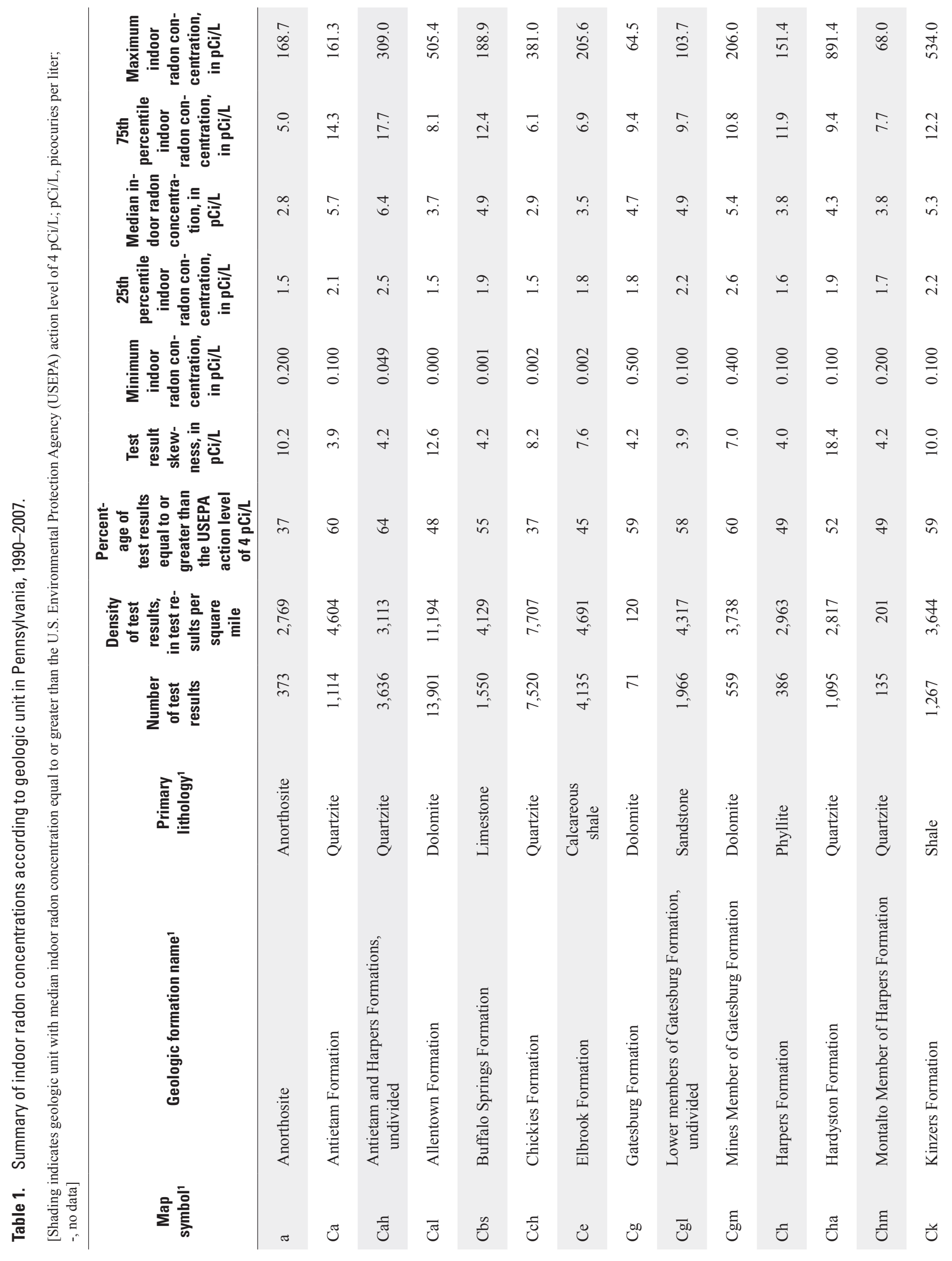




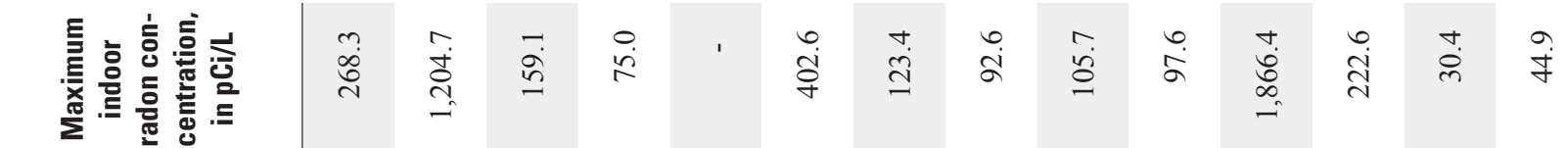

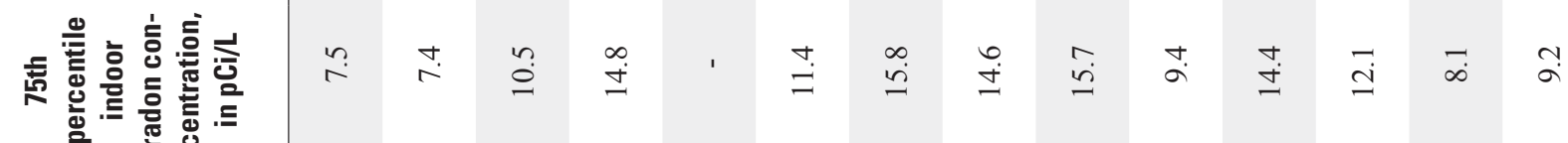

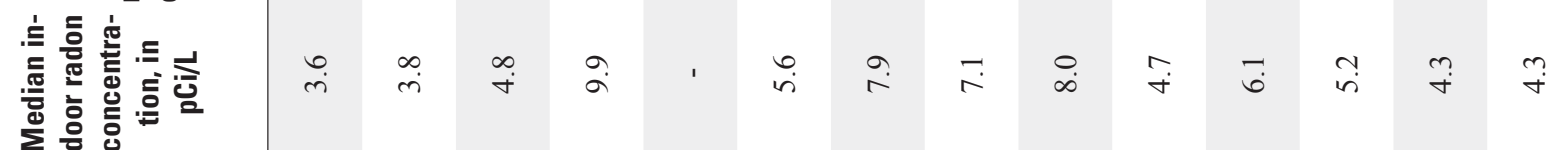

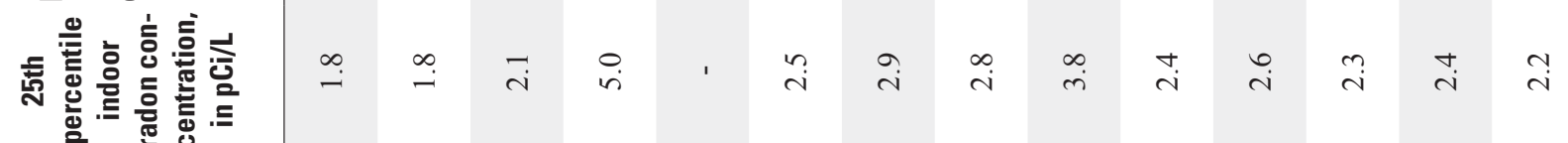

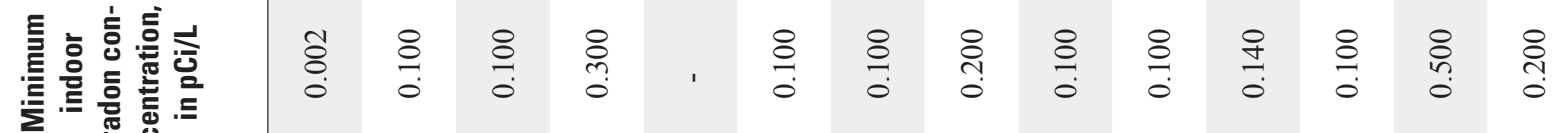

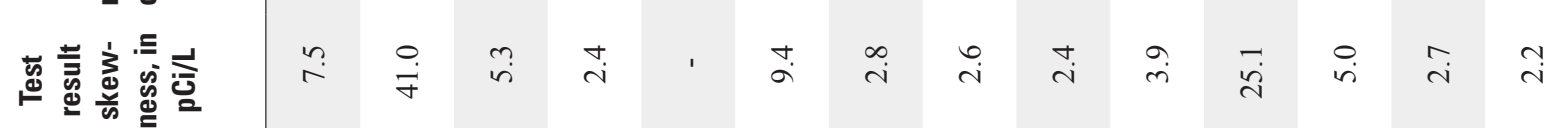

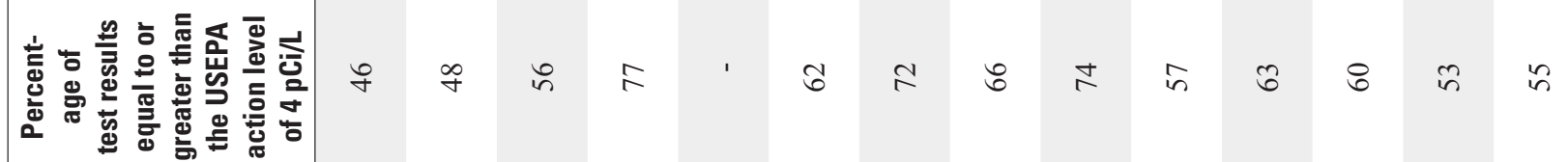

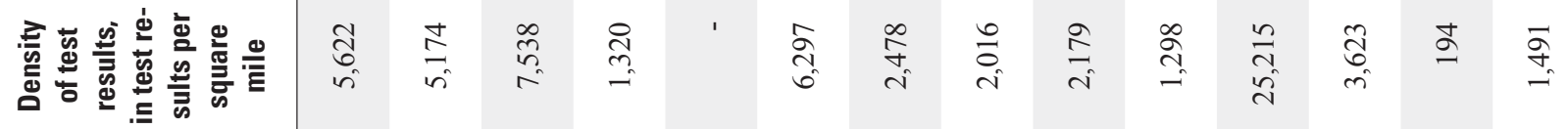

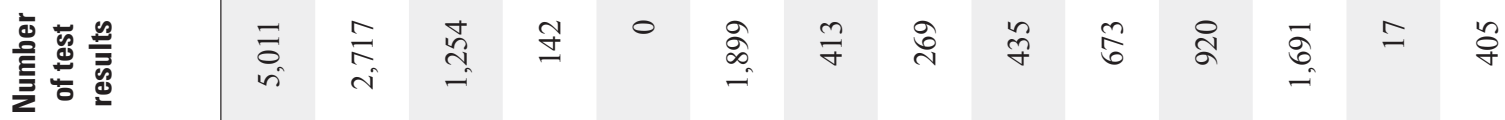
를 츨

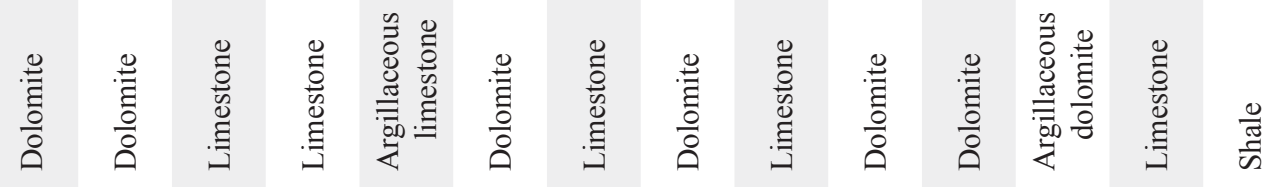

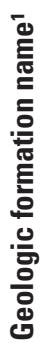

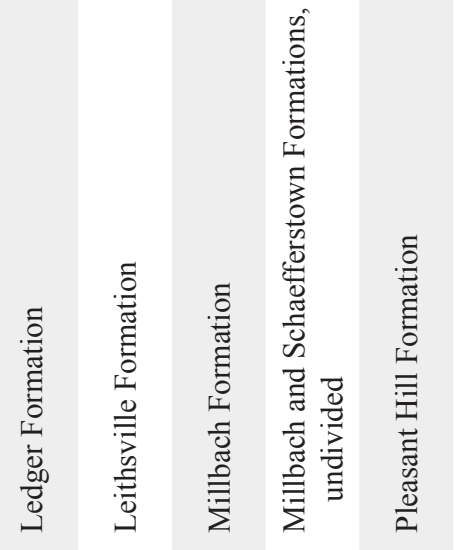
产 $\frac{\bar{c}}{\bar{c}}$

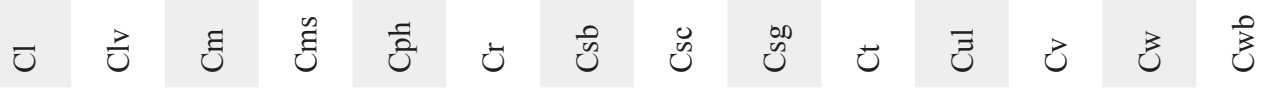




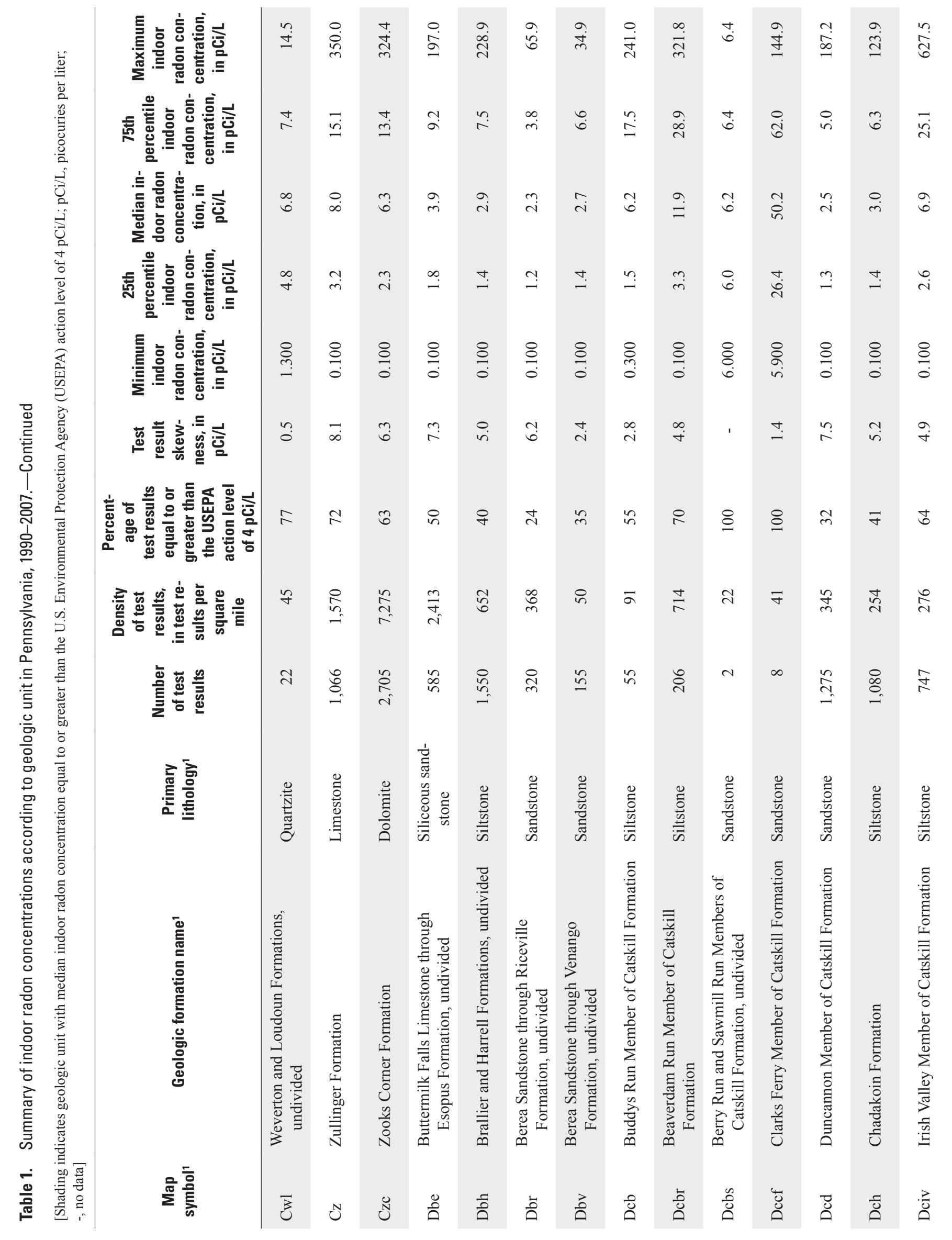




\begin{tabular}{|c|c|c|c|c|c|c|c|c|c|c|c|c|c|}
\hline 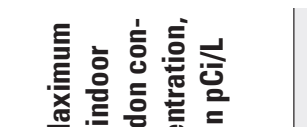 & $\vec{p}$ & 迎 & D & 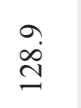 & in & $\stackrel{\varrho}{\cong}$ & ڤ్ & $\stackrel{\leftrightarrow}{\sigma}$ & $\dot{\bar{m}}$ & సَ & $\stackrel{\leftrightarrow}{\varrho}$ & if & $\underline{6}$ \\
\hline 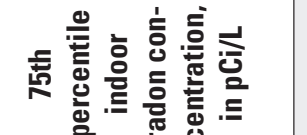 & in & $\stackrel{\infty}{=}$ & g & 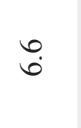 & in & q & $\stackrel{\infty}{0}$ & $\stackrel{ \pm}{ \pm}$ & తి & 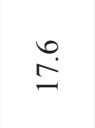 & 䓅 & $\stackrel{ \pm}{ \pm}$ & $\stackrel{\infty}{+}$ \\
\hline 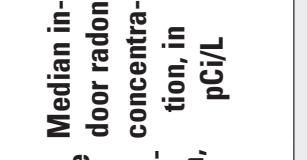 & 요 & $\stackrel{\infty}{+}$ & $\stackrel{i}{i}$ & ذ્ & $\bar{i}$ & a & $\stackrel{+}{+}$ & $n$ & $\stackrel{q}{q}$ & $\dot{n}$ & ${ }_{\infty}^{\circ}$ & $\mathrm{m}$ & 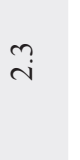 \\
\hline 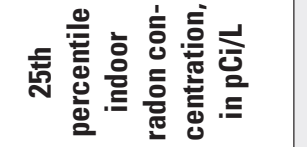 & $\stackrel{\circ}{\circ}$ & $\stackrel{9}{9}$ & 3 & $\cong$ & 3 & $=$ & $=$ & $\stackrel{\infty}{-}$ & $\stackrel{i}{i}$ & $\stackrel{g}{=}$ & a & $\stackrel{\circ}{-}$ & $\equiv$ \\
\hline & $\frac{8}{0}$ & $\frac{8}{0}$ & $\frac{8}{0}$ & 윰 & $\frac{8}{0}$ & $\frac{8}{0}$ & $\frac{8}{0}$ & $\frac{8}{0}$ & \%్రి & 总 & $\frac{8}{0}$ & ఫ్రి & $\frac{8}{0}$ \\
\hline 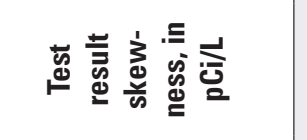 & 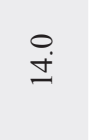 & $\stackrel{\circ}{\circ}$ & $\stackrel{i}{i}$ & $\infty$ & f & $\infty$ & $\vec{\infty}$ & $\therefore$ & $\vec{j}$ & 亲 & $\bar{i}$ & $\stackrel{i}{i}$ & 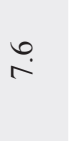 \\
\hline 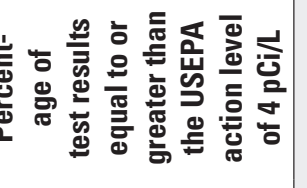 & 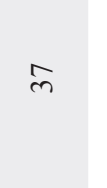 & $\therefore$ & $\approx$ & q & 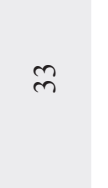 & $\stackrel{\circ}{ }$ & $\stackrel{\infty}{q}$ & in & in & $\therefore$ & t & $\therefore$ & ${ }_{m}$ \\
\hline 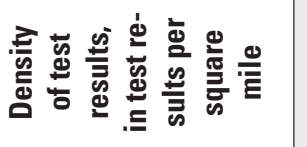 & $\stackrel{\circ}{n}$ & 莺 & $\frac{n}{n}$ & g & $\overline{6}$ & $\Xi$ & $\stackrel{\infty}{\infty}$ & 必 & Бू & 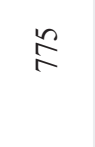 & 志 & $\bar{a}$ & 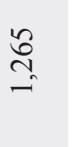 \\
\hline 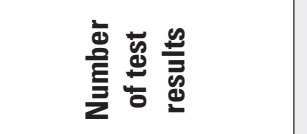 & 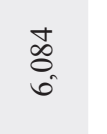 & $\stackrel{t}{3}$ & 驾 & $\Xi$ & $\stackrel{\circ}{\circ}$ & 字 & 5 & $\underline{\vec{g}}$ & $\bar{ন}$ & $\nexists$ & in & $\neq$ & 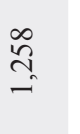 \\
\hline
\end{tabular}

层毫

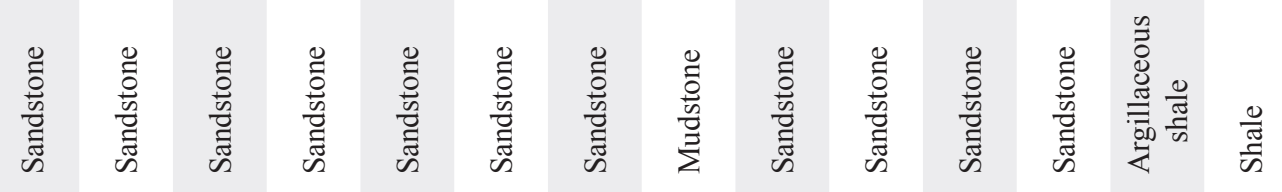

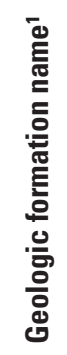
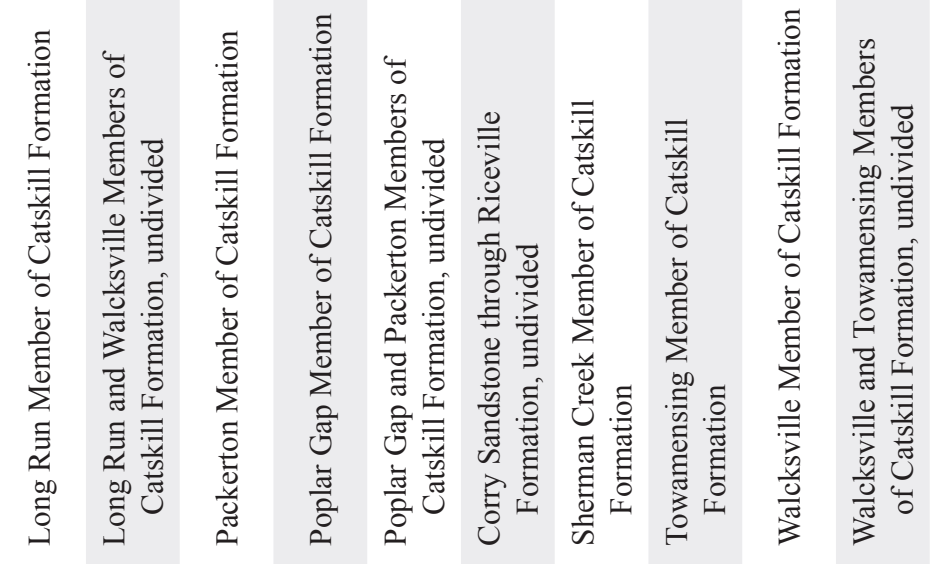

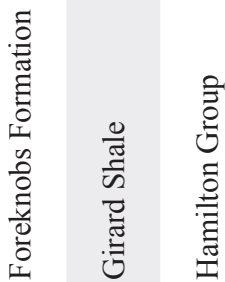

言变

高高

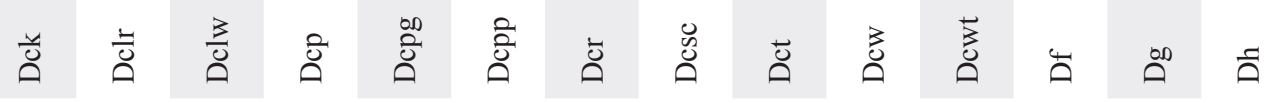




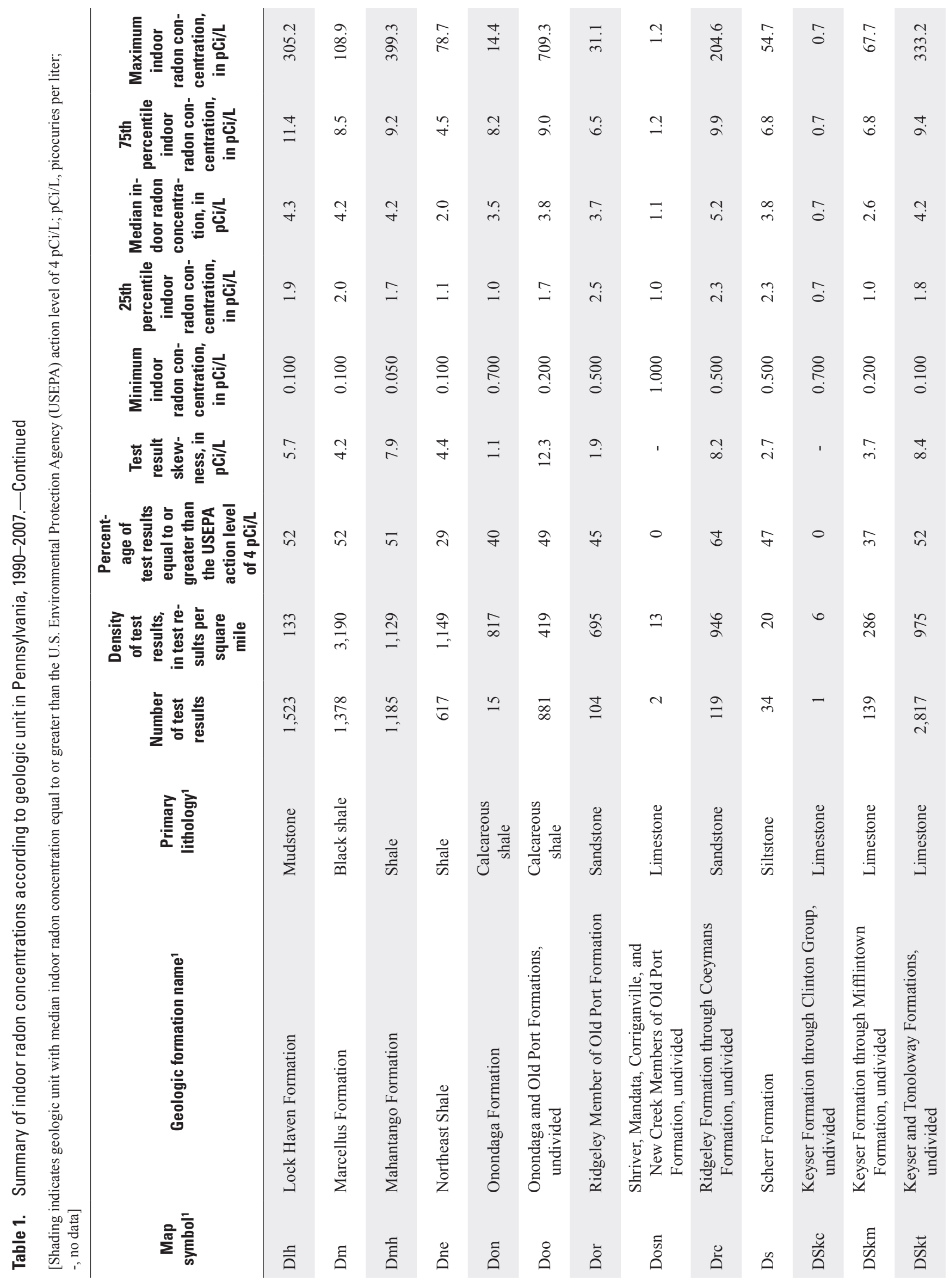




\begin{tabular}{|c|c|c|c|c|c|c|c|c|c|c|c|c|c|c|}
\hline 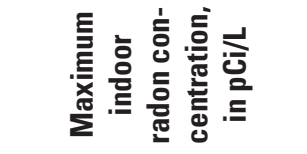 & $\frac{+}{\infty}$ & $\begin{array}{l}\text { ¿্రু } \\
\text {. }\end{array}$ & $\begin{array}{l}\text { iे } \\
\text { ర్d }\end{array}$ & $\begin{array}{l}n \\
\infty \\
\infty\end{array}$ & $\stackrel{\circ}{\circ}$ & $\underset{\stackrel{+}{I}}{\stackrel{2}{I}}$ & 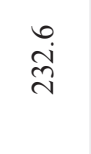 & $\begin{array}{l}\infty \\
\stackrel{\Theta}{I} \\
=\end{array}$ & $\stackrel{\grave{2}}{\grave{2}}$ & $\begin{array}{l}\stackrel{0}{0} \\
\text { ñ } \\
-1\end{array}$ & ?̊ & 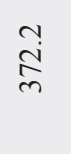 & 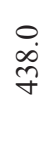 & గై \\
\hline 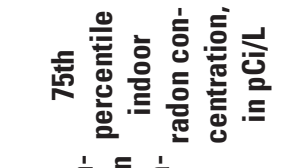 & $\stackrel{\infty}{0}_{0}$ & $\stackrel{\Upsilon}{2}$ & $\stackrel{\circ}{r}$ & के & $\ddot{n}$ & $\begin{array}{l}n \\
\stackrel{n}{n}\end{array}$ & గి & $\stackrel{a}{r}$ & $\stackrel{\vec{n}}{\vec{n}}$ & $\vec{m}$ & $\stackrel{\circ}{r}$ & $\tilde{a}$ & in & $\stackrel{+}{\infty}$ \\
\hline 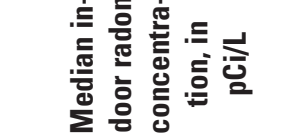 & $\stackrel{b}{\dot{r}}$ & $\begin{array}{l}\infty \\
\dot{n}\end{array}$ & $\stackrel{\circ}{\dot{r}}$ & $\vec{i}$ & $\vec{i}$ & $\stackrel{\nabla}{\sigma}$ & $\vec{m}$ & ஸे & $\hat{i}$ & $\stackrel{\vartheta}{+}$ & $\ddot{n}$ & $\stackrel{\circ}{+}$ & $\stackrel{\infty}{i}$ & $\stackrel{\odot}{+}$ \\
\hline 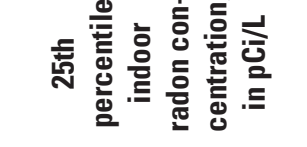 & $\stackrel{\nabla}{i}$ & $\vec{i}$ & $\stackrel{\text { กִ }}{-}$ & $\exists$ & $\stackrel{\text { Iִ }}{-}$ & $\dot{m}$ & $\stackrel{ \pm}{-}$ & $\stackrel{n}{\sim}$ & $\stackrel{ \pm}{-}$ & $\stackrel{\circ}{i}$ & $\stackrel{6}{\circ}$ & $\stackrel{\infty}{-}$ & $\stackrel{ \pm}{-}$ & $\tilde{i}$ \\
\hline 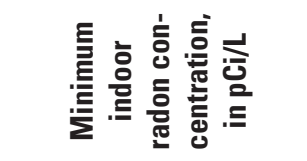 & $\begin{array}{l}\text { ¿े } \\
\text { ๖े }\end{array}$ & $\frac{8}{0}$ & $\frac{8}{0}$ & $\frac{8}{0}$ & $\begin{array}{l}8 \\
\vdots \\
0\end{array}$ & $\begin{array}{l}\text { ̊े } \\
\text { ஸ̣ }\end{array}$ & $\frac{8}{0}$ & $\frac{8}{0}$ & : & $\frac{8}{0}$ & $\stackrel{\circ}{\circ}$ & $\frac{8}{0}$ & $\frac{8}{8}$ & $\begin{array}{l}8 \\
\vdots \\
0\end{array}$ \\
\hline 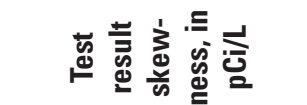 & 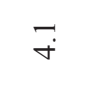 & in & $\stackrel{?}{\varrho}$ & $\tilde{\sigma}$ & 卞 & $\vec{i}$ & ?ู & $\stackrel{\infty}{\text { I }}$ & $\overrightarrow{\stackrel{\oplus}{~}}$ & $\begin{array}{l}0 \\
\dot{J}\end{array}$ & $\stackrel{\sim}{+}$ & $\stackrel{\nabla}{\infty}$ & $\stackrel{\infty}{\stackrel{\sim}{~}}$ & $\tilde{n}$ \\
\hline 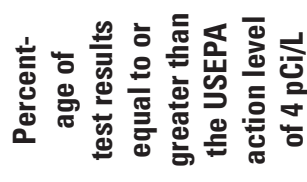 & 于 & $\vec{\sigma}$ & F & $\approx$ & ิ & $\mathbb{N}$ & के & $\mathscr{f}$ & $\ddot{n}$ & in & fo & $\bar{n}$ & ల & $\stackrel{\circ}{n}$ \\
\hline 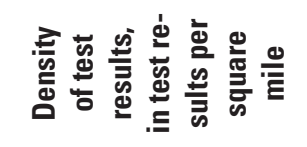 & $\underset{0}{\infty}$ & ஓ्̀ & ‡ి & 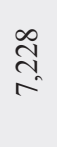 & $\begin{array}{l}\infty \\
\stackrel{0}{0} \\
\stackrel{0}{=}\end{array}$ & $\begin{array}{l}\infty \\
\stackrel{\infty}{ } \\
\infty \\
\stackrel{\sim}{1}\end{array}$ & 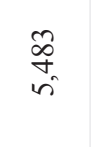 & $\begin{array}{l}\text { D̃ } \\
\text { in }\end{array}$ & \begin{tabular}{l}
0 \\
\multirow{b}{0}{} \\
0
\end{tabular} & $\stackrel{ }{\approx}$ & 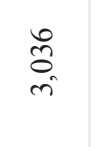 & $\stackrel{\vec{\nabla}}{=}$ & $\underset{-}{\stackrel{్}{~}}$ & 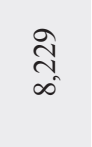 \\
\hline 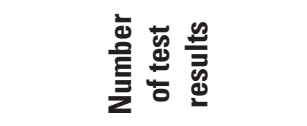 & $\stackrel{\infty}{\sim}$ & $\stackrel{m}{=}$ & $\frac{\circ}{a}$ & 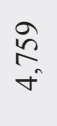 & 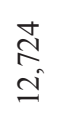 & $\stackrel{\sim}{\sim}$ & $\begin{array}{l}\stackrel{m}{\vec{v}} \\
\underset{i}{n}\end{array}$ & $\underset{\sim}{\stackrel{\Xi}{\leftrightarrows}}$ & $\begin{array}{l}\stackrel{2}{\Omega} \\
\hat{n}\end{array}$ & $\begin{array}{l}m \\
\stackrel{n}{n} \\
i\end{array}$ & $\stackrel{0}{0}$ & $\stackrel{n}{6}$ & $\underset{\stackrel{\mathbb{N}}{i}}{\stackrel{i}{i}}$ & $\approx$ \\
\hline 高 & 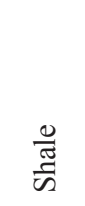 & 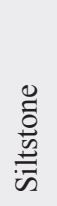 & 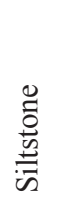 & 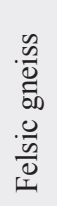 & 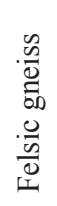 & 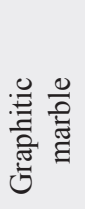 & 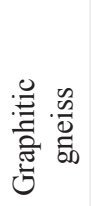 & 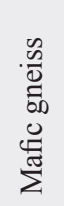 & 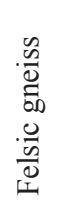 & $\begin{array}{l}\frac{w}{0} \\
\frac{0}{0} \\
\tilde{D}_{0} \\
\frac{0}{0} \\
\frac{0}{0} \\
\frac{1}{1}\end{array}$ & 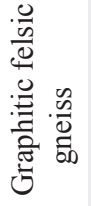 & 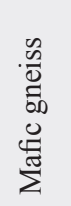 & 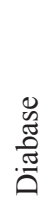 & 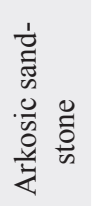 \\
\hline 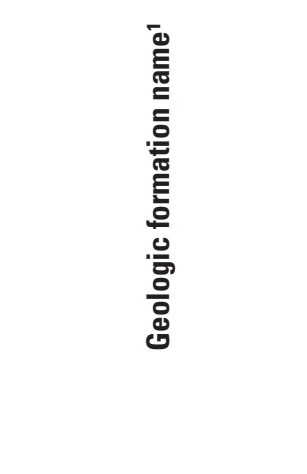 & 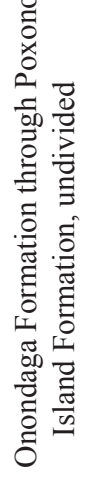 & 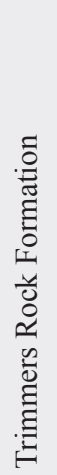 & 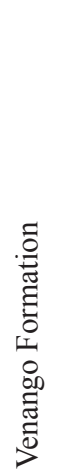 & 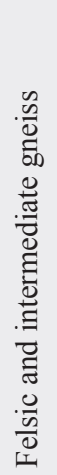 & 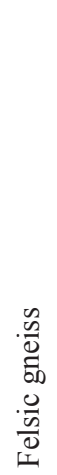 & 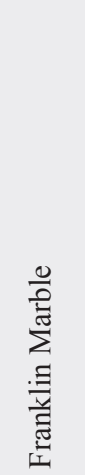 & 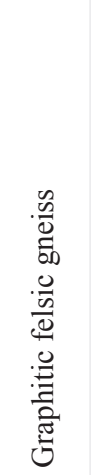 & 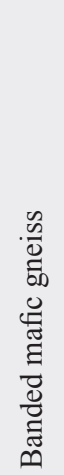 & 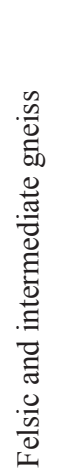 & 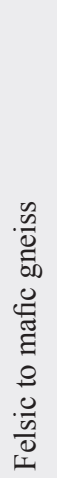 & 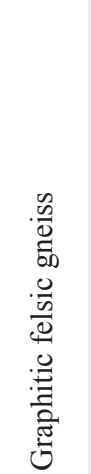 & 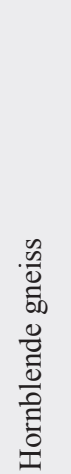 & 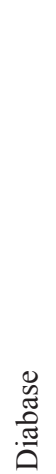 & 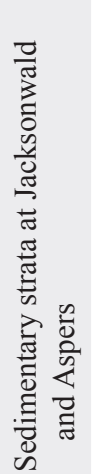 \\
\hline$\sum$ & $\begin{array}{l}\text { वे } \\
\text { مी }\end{array}$ & ثี & $\vec{n}$ & $+\infty$ & 怒 & $\Xi$ & - & 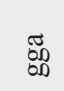 & 总 & हू & 竞 & $\stackrel{\infty 00}{I}$ & $\Xi$ & $\cong$ \\
\hline
\end{tabular}




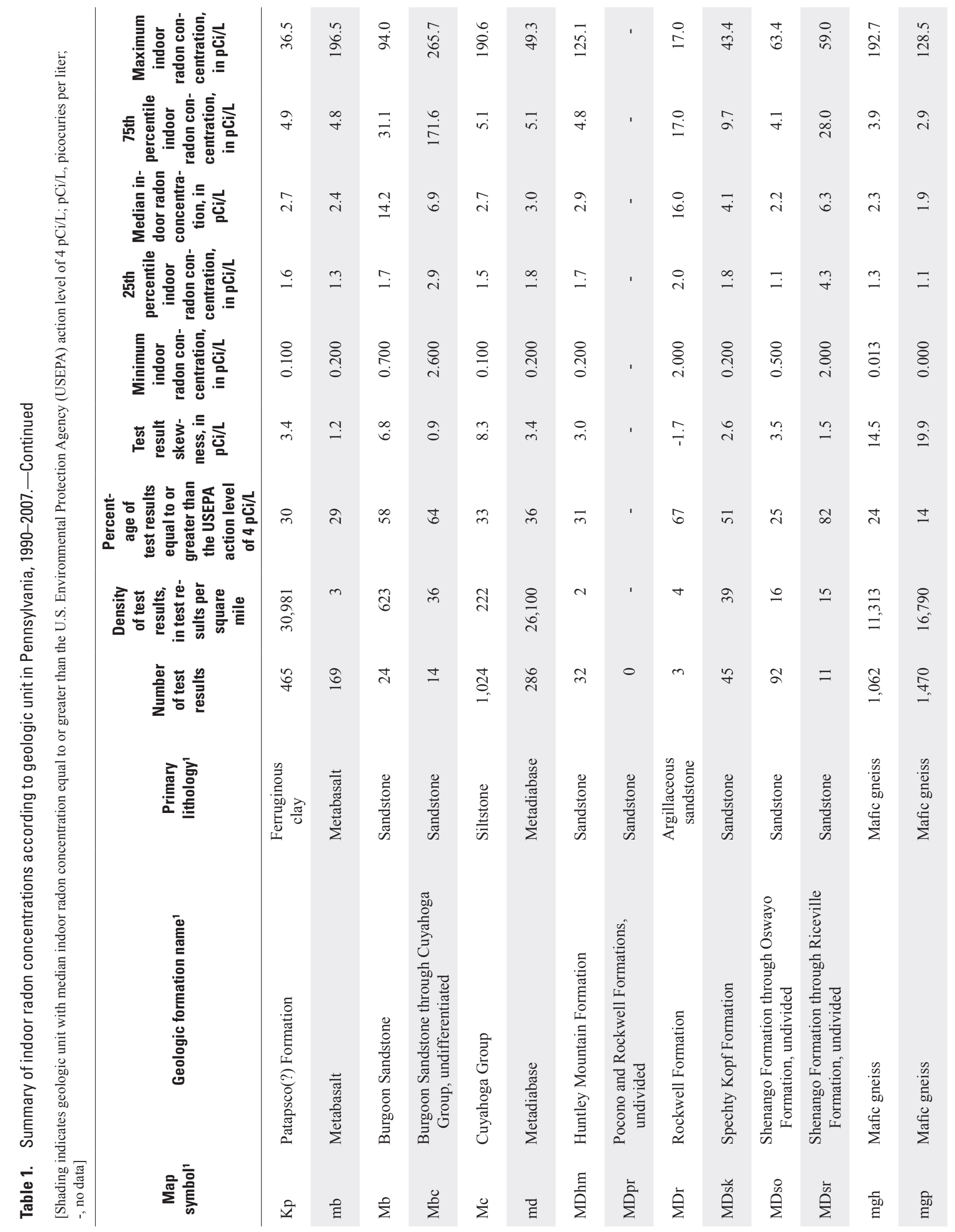




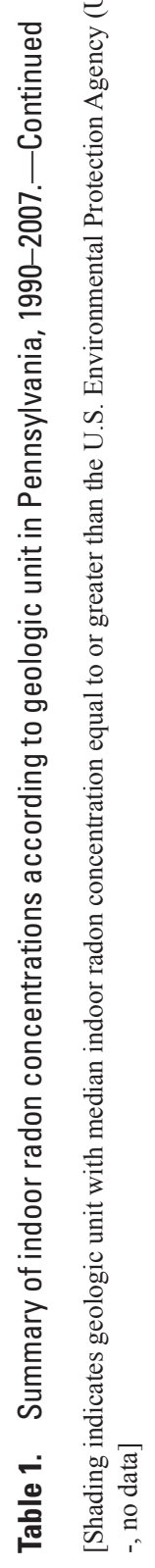

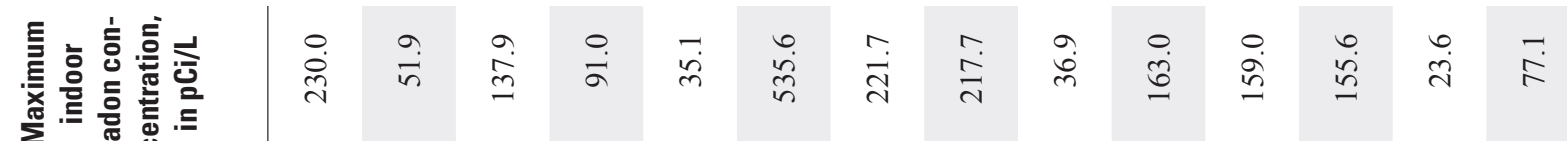

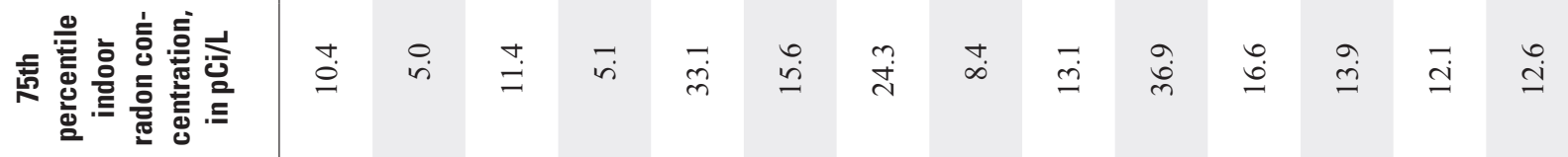

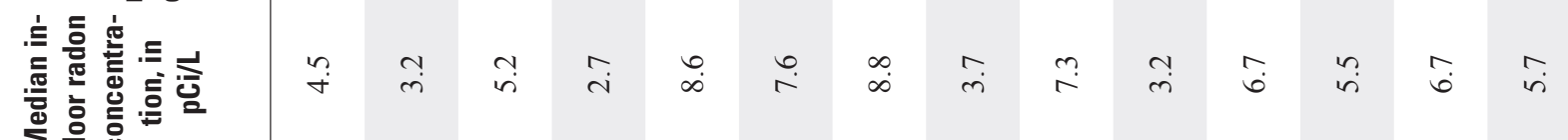

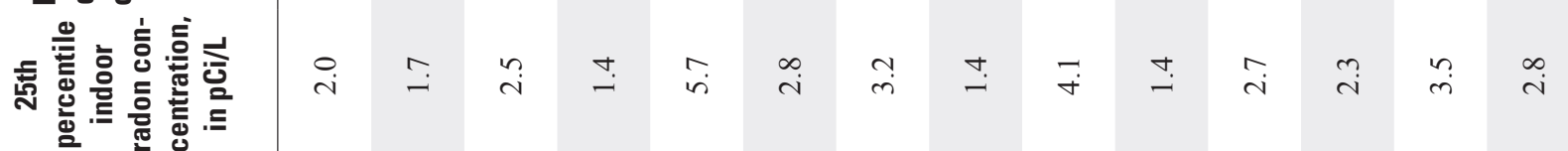

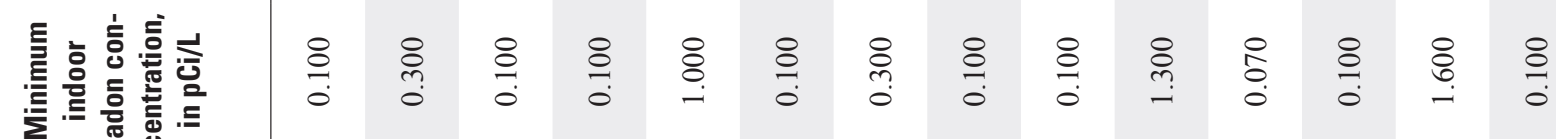

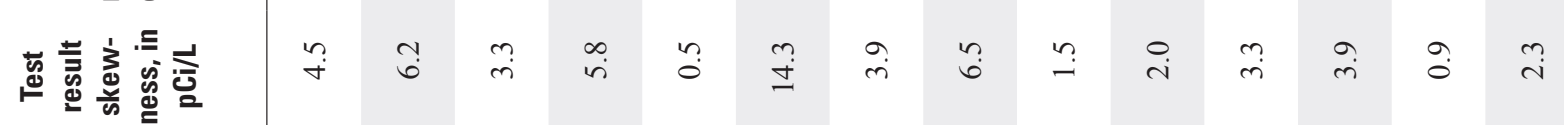

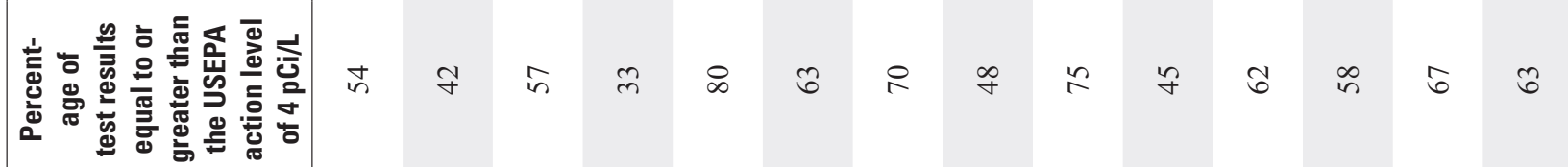

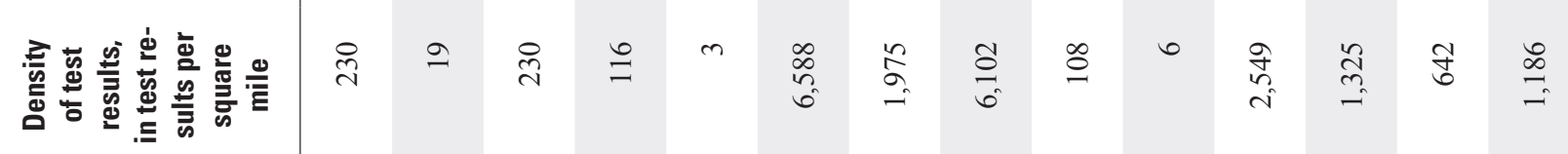

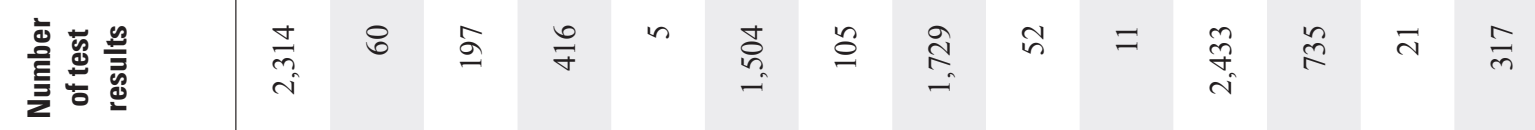

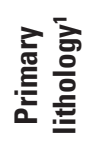

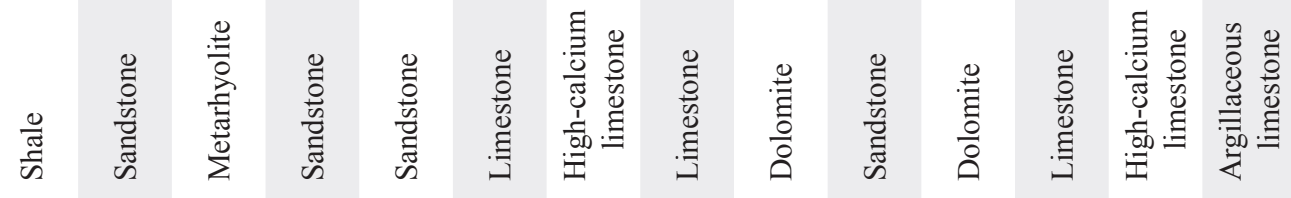
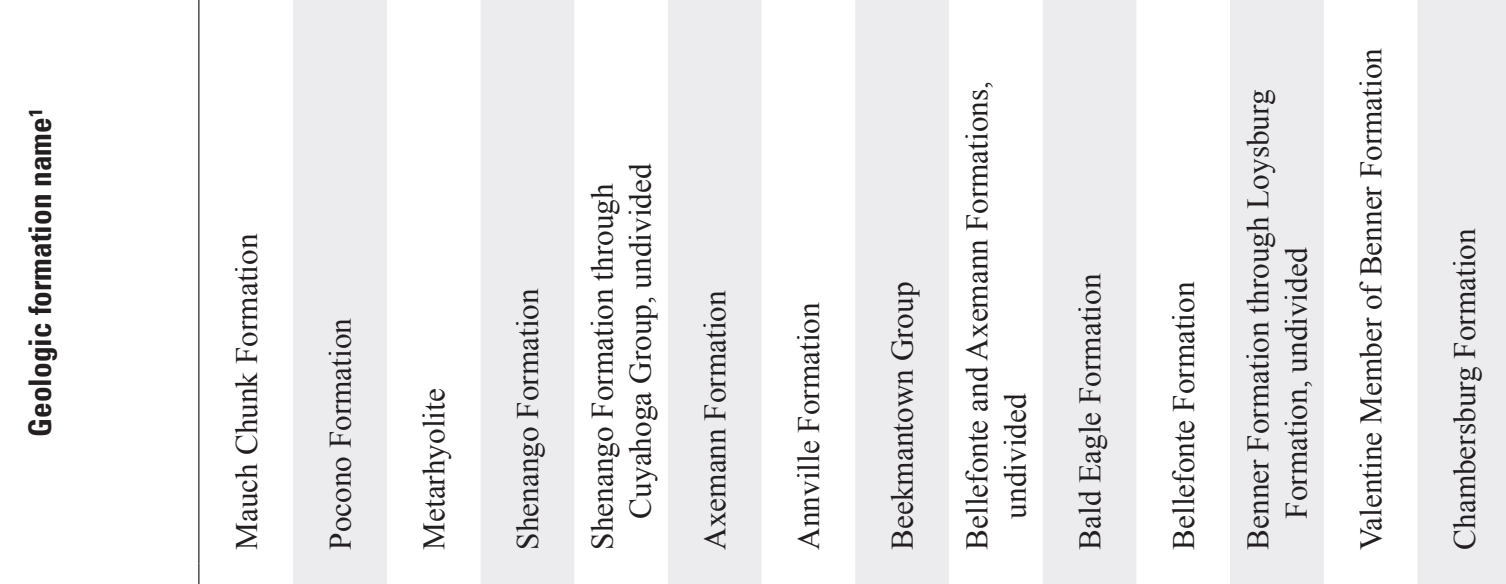

高高

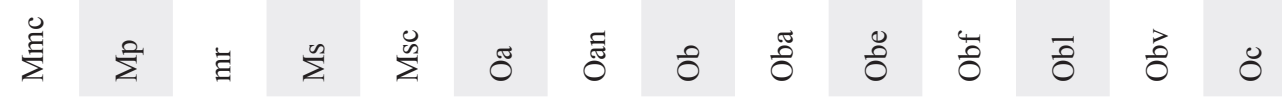




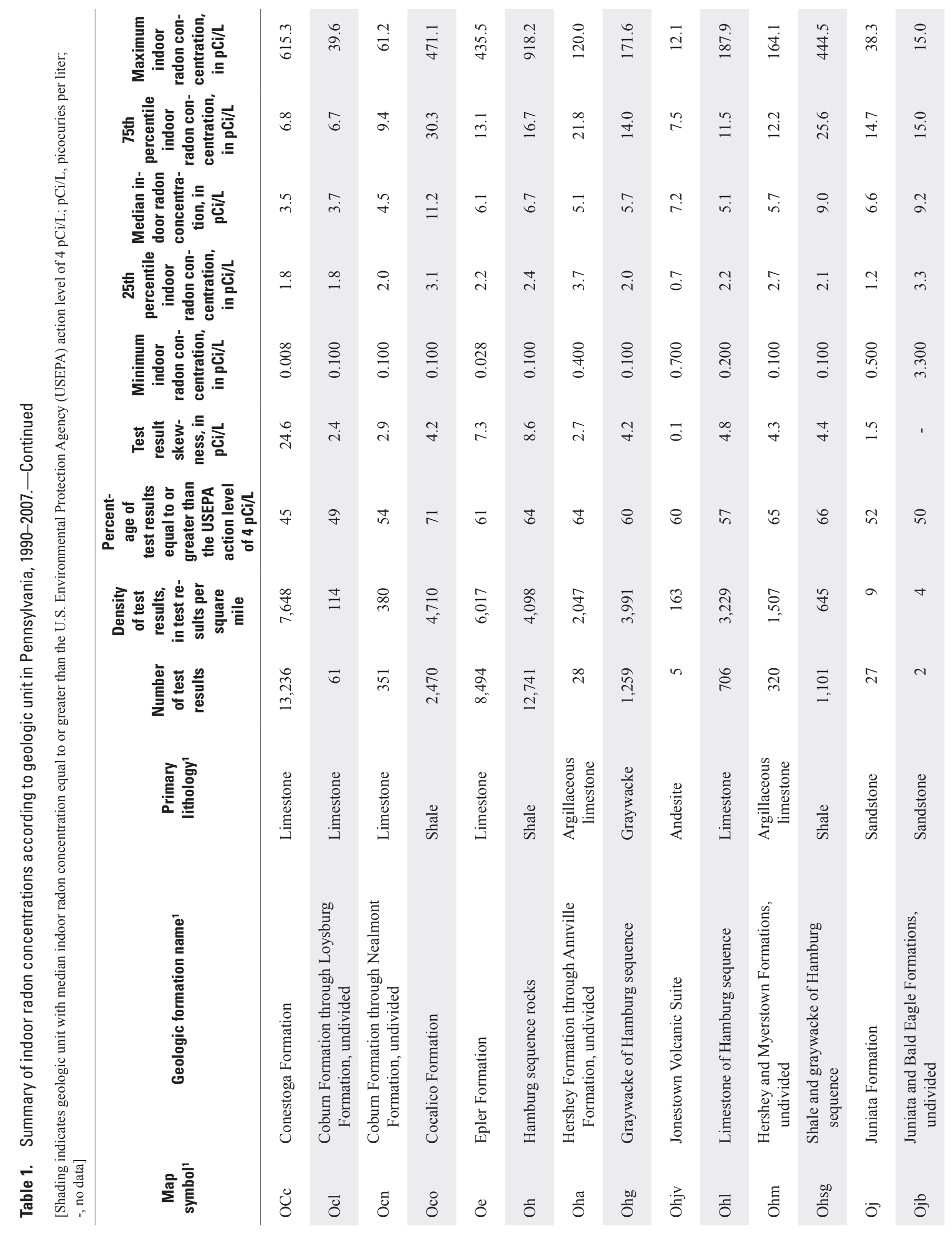




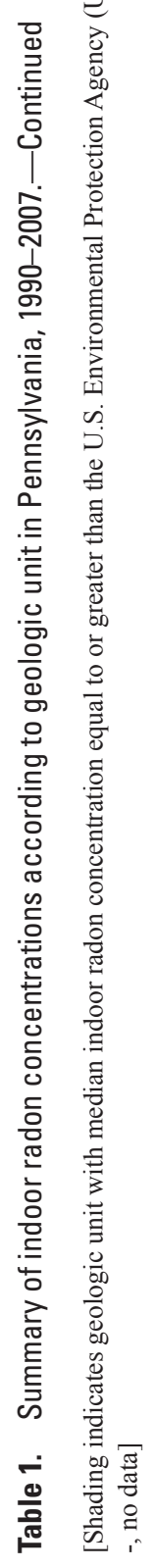

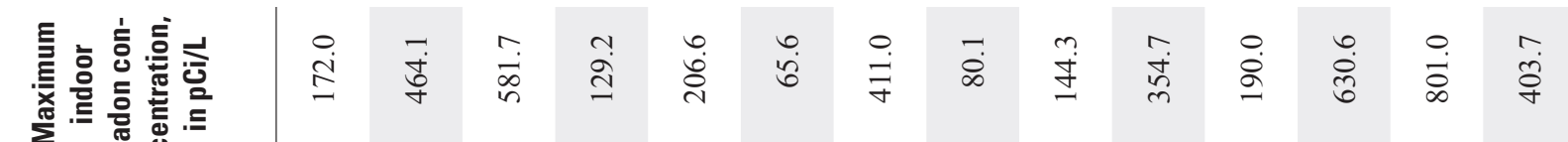

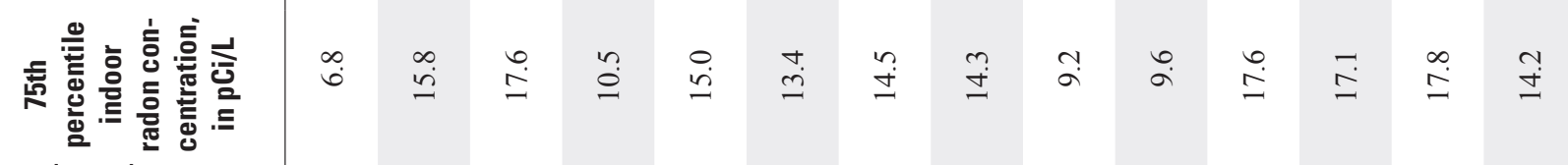

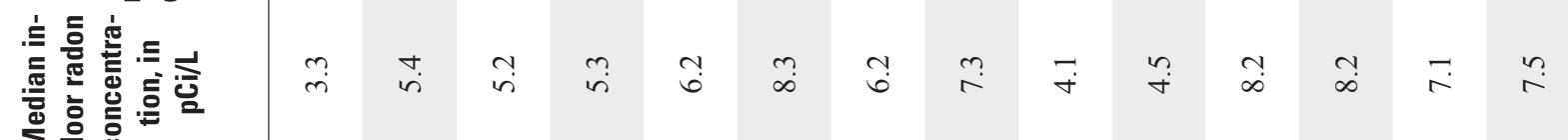

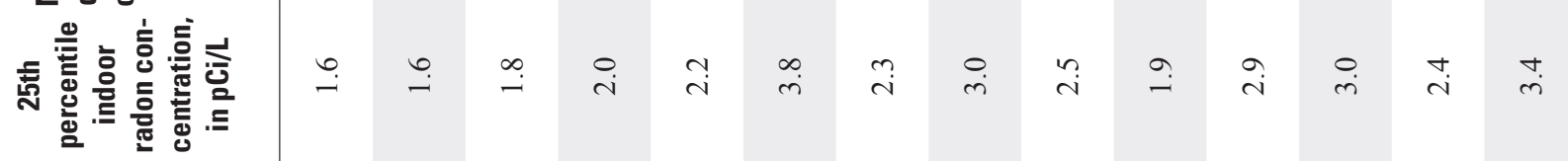

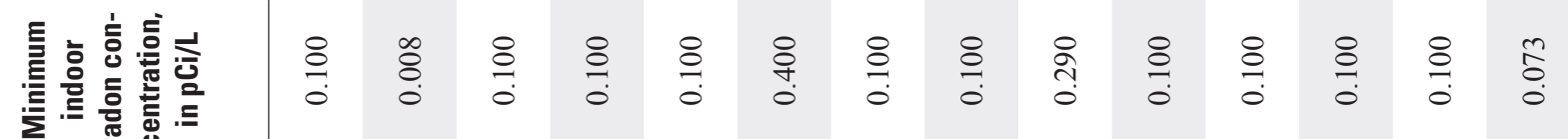

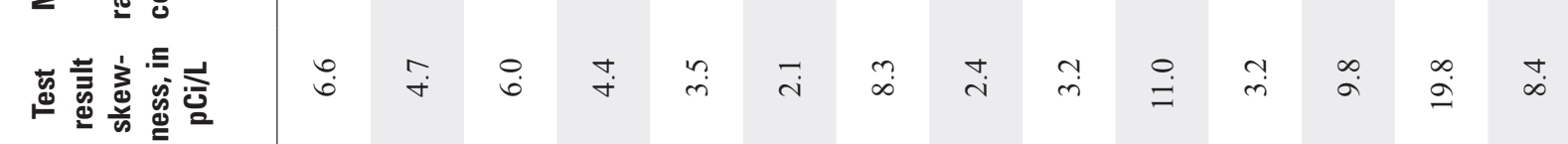

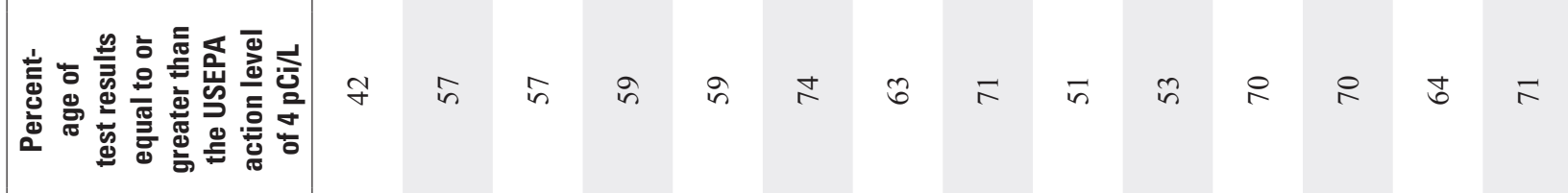

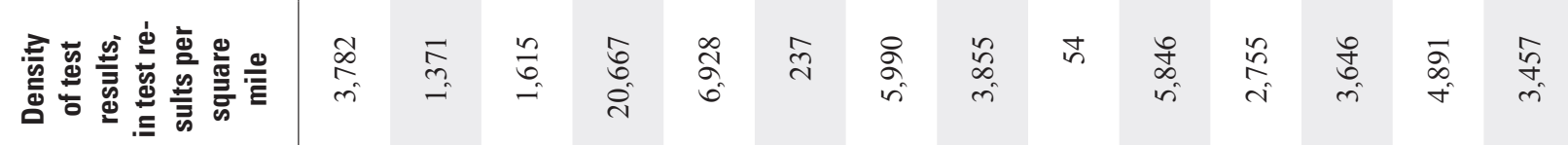

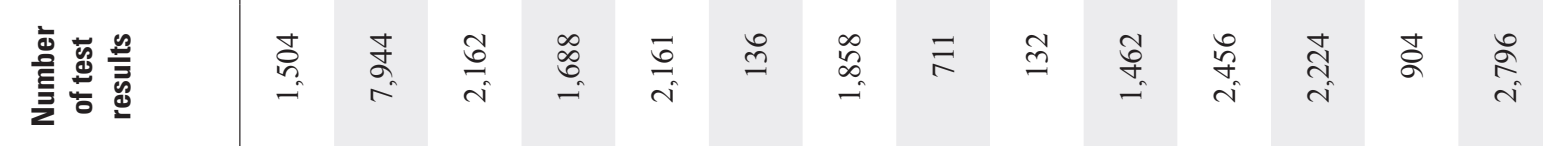
层高

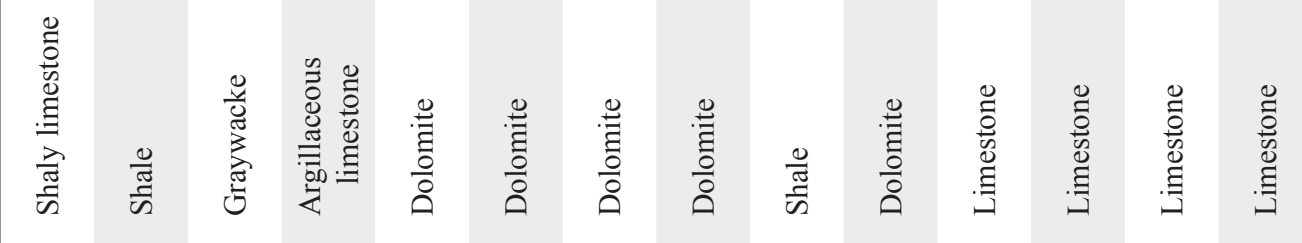
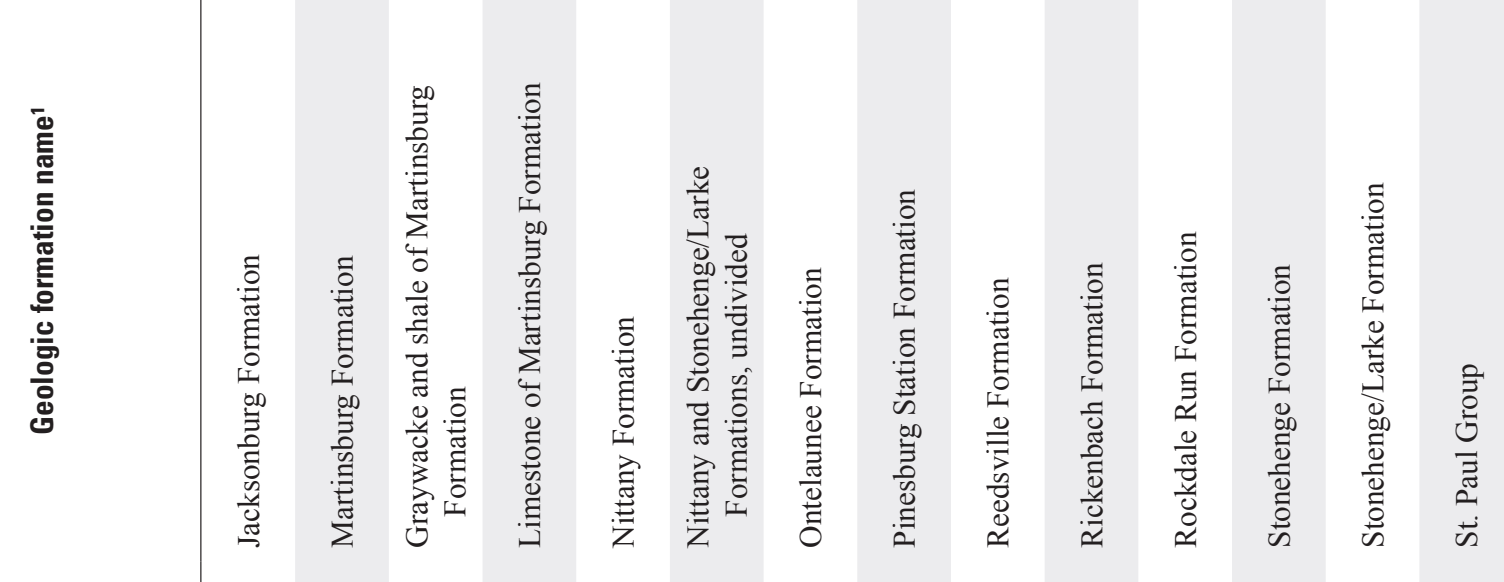

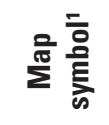

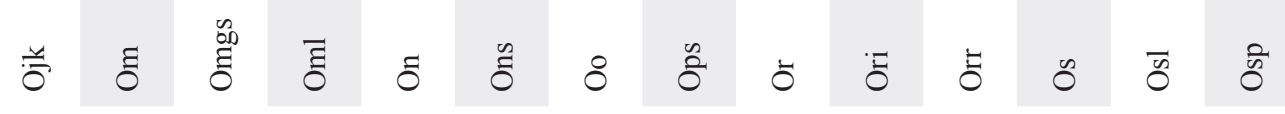




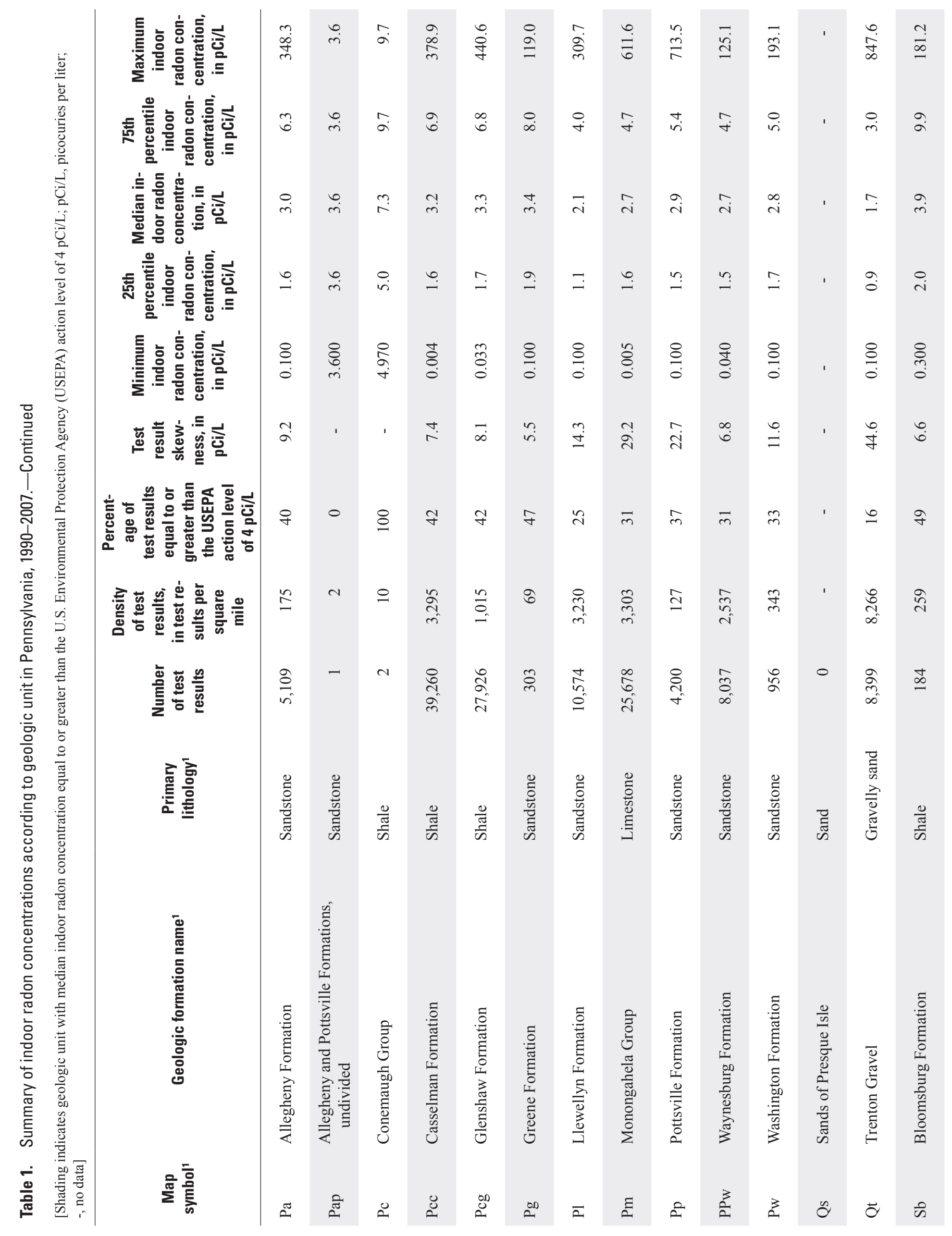




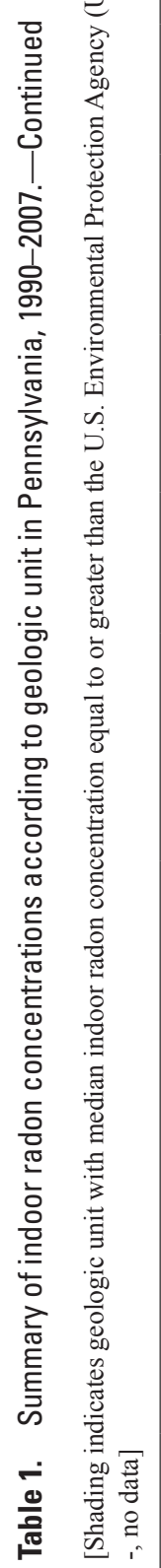

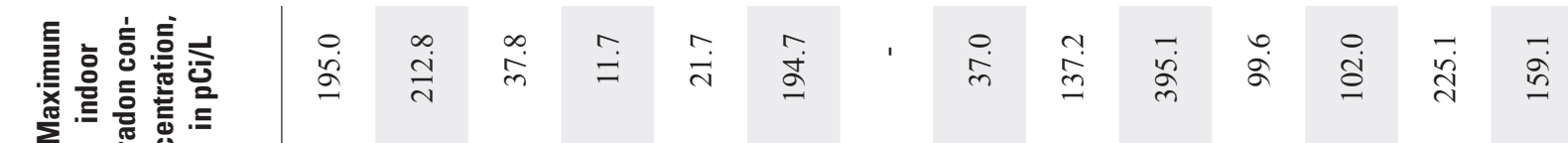

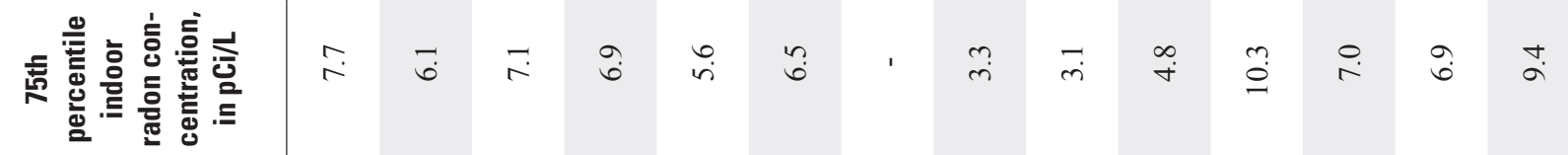

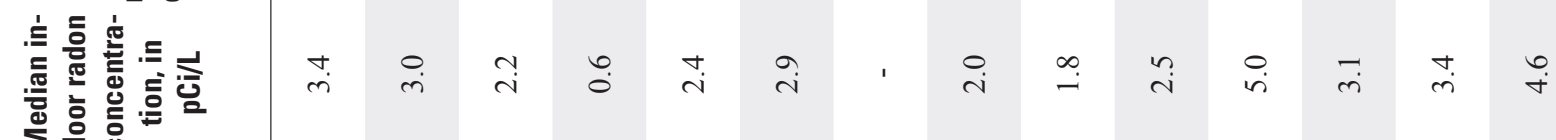

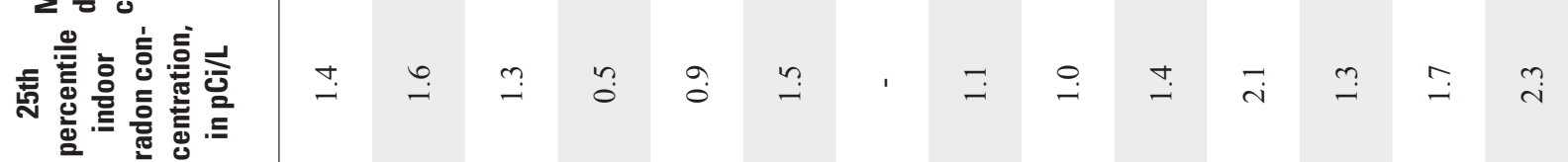

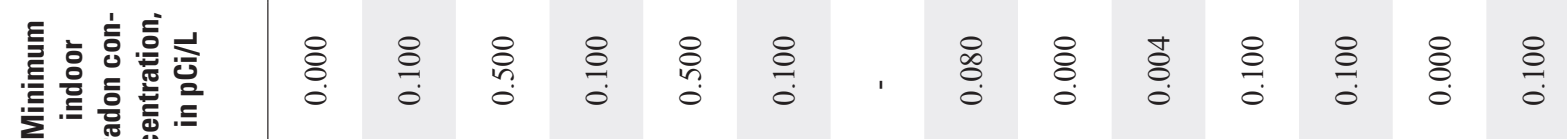

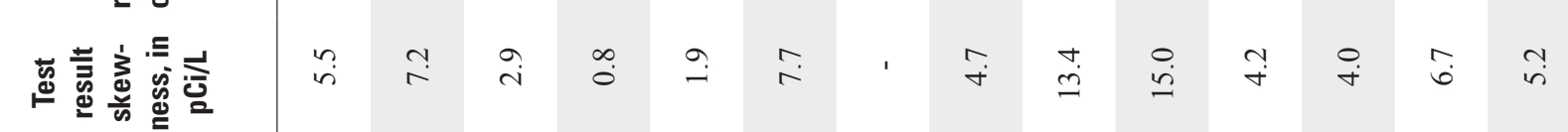

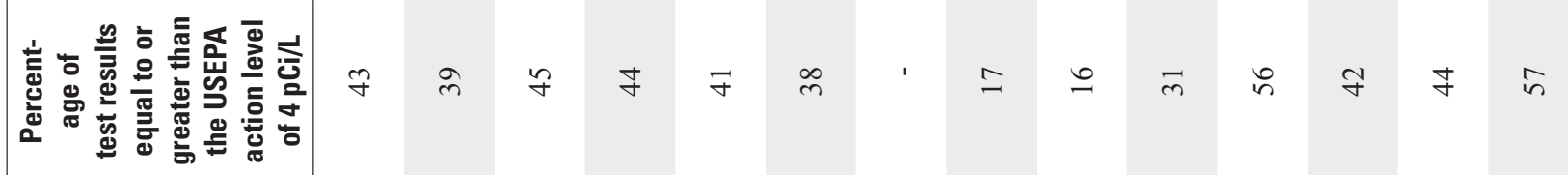

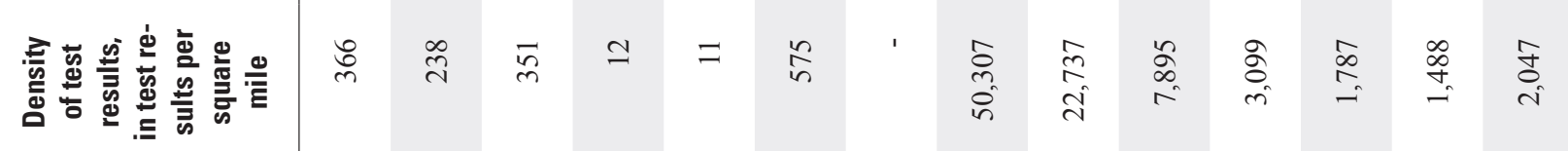

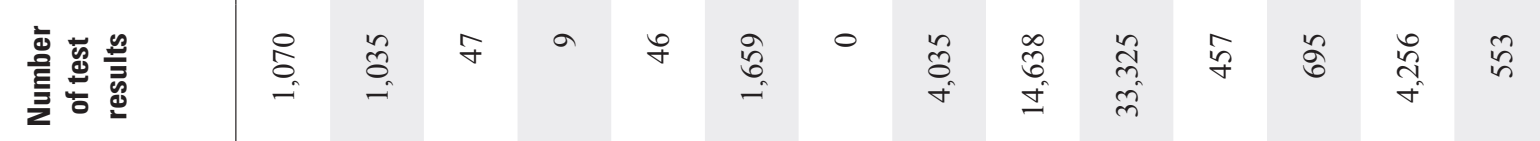

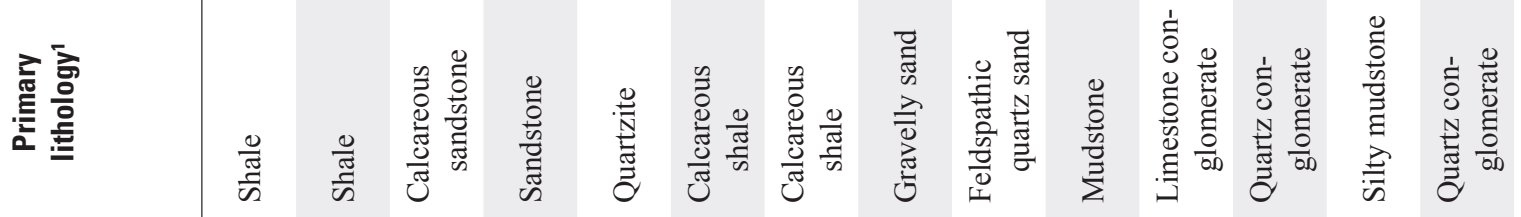
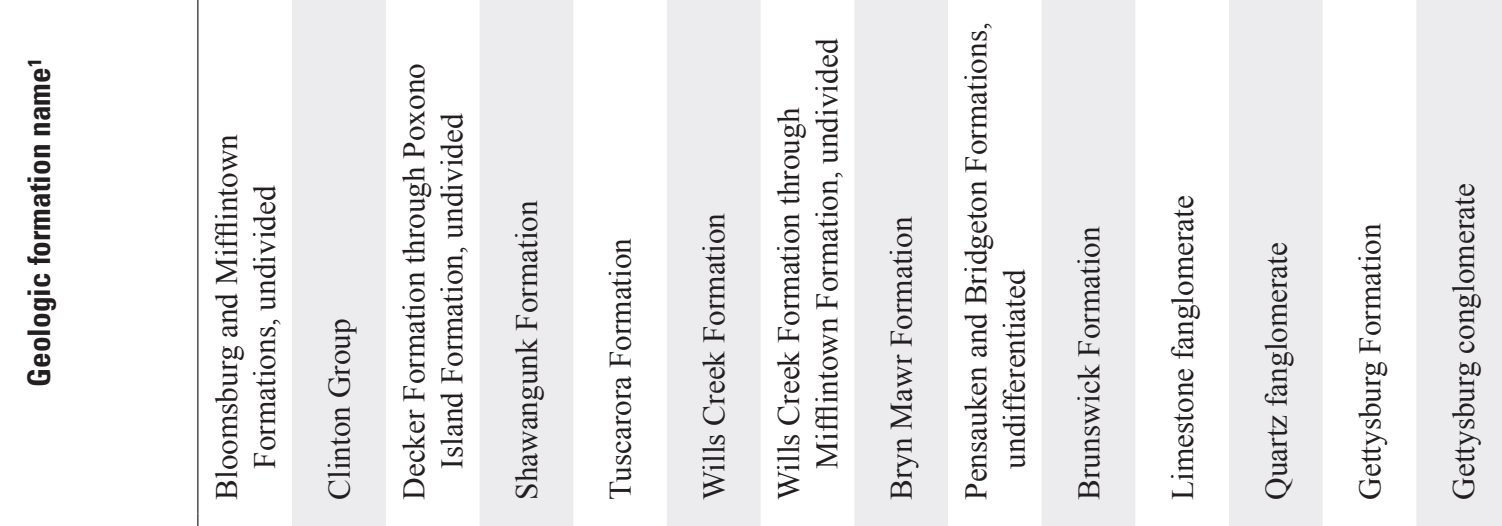

高高

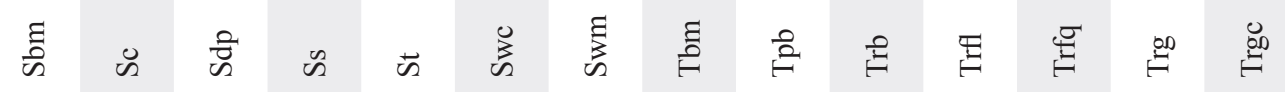




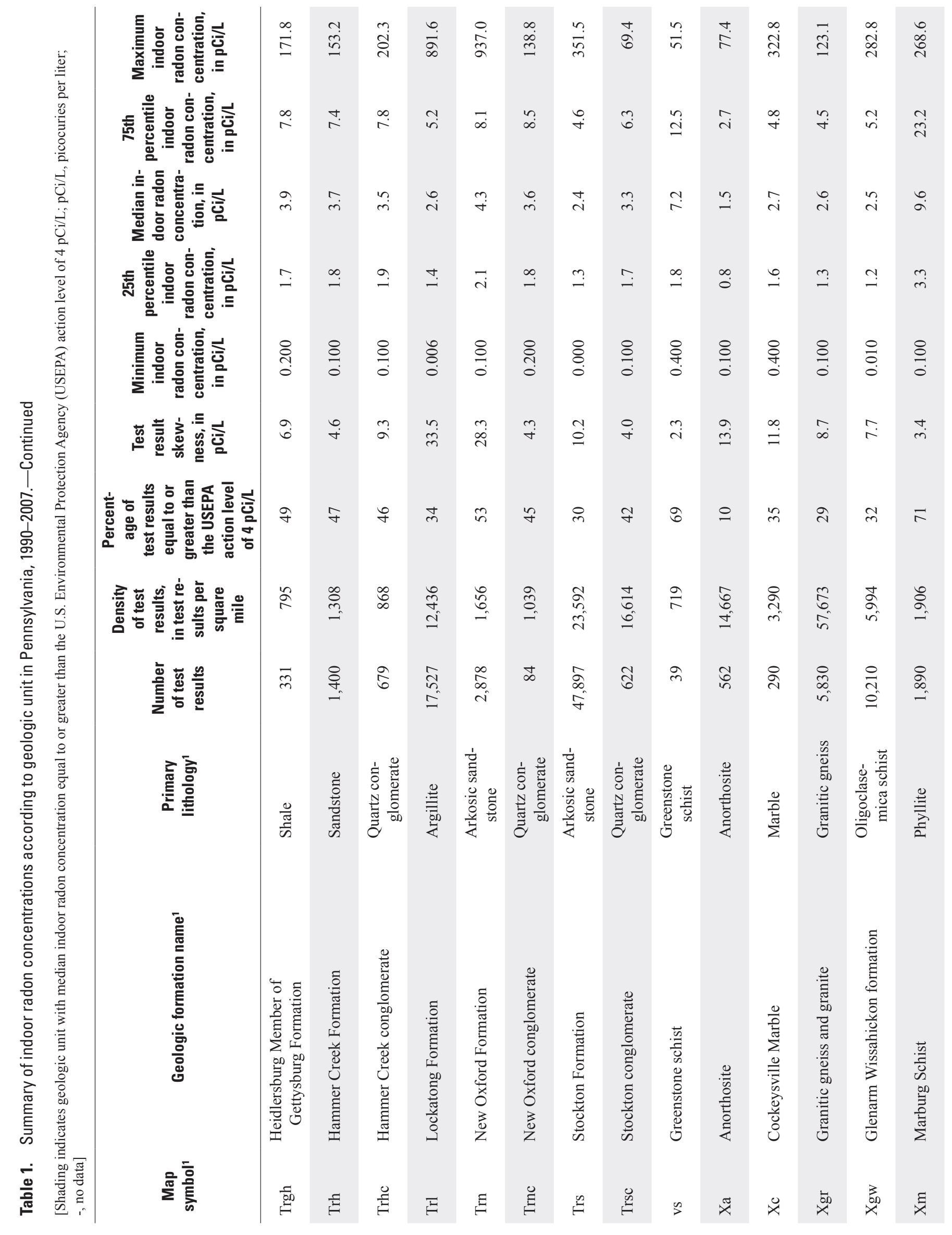




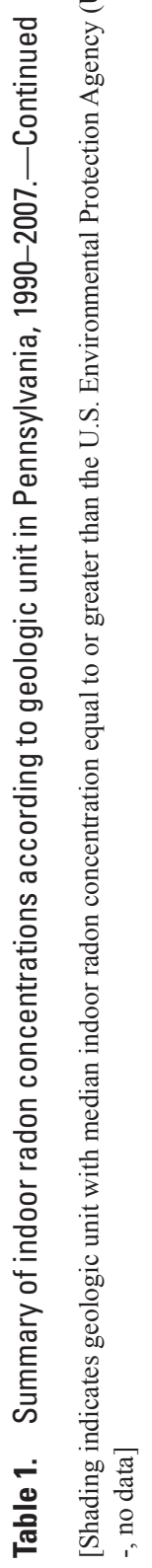

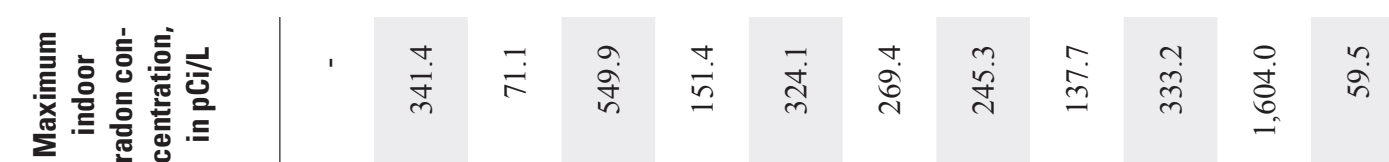

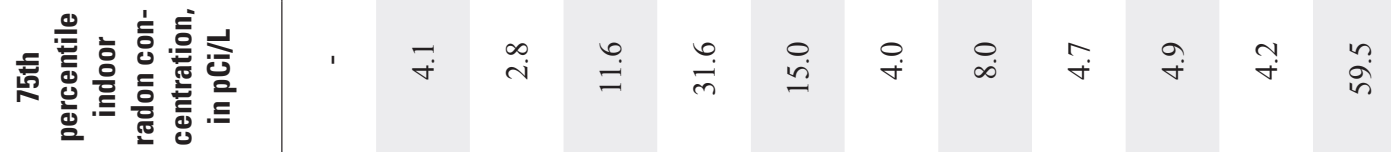

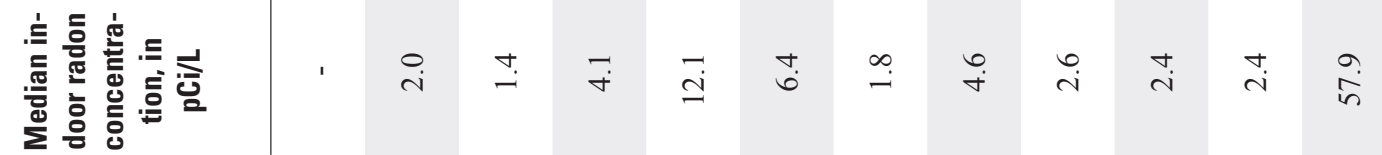

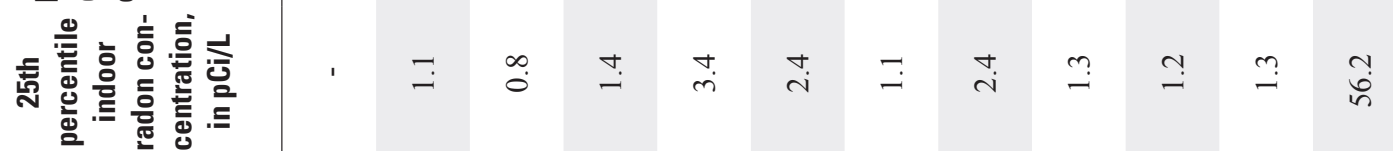

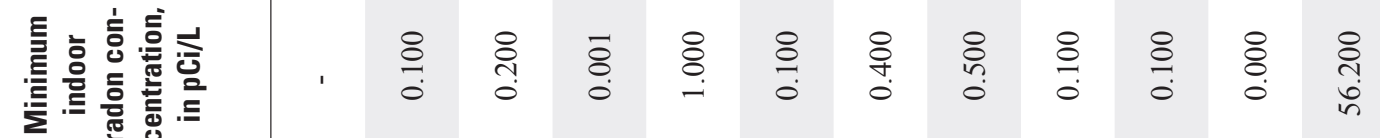

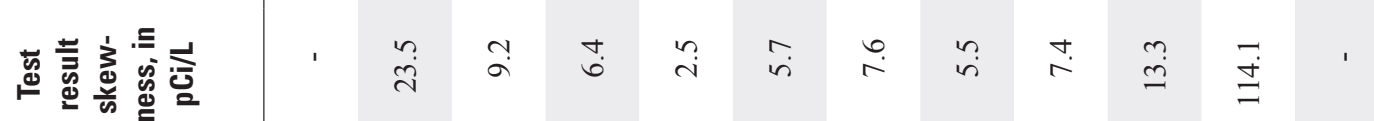

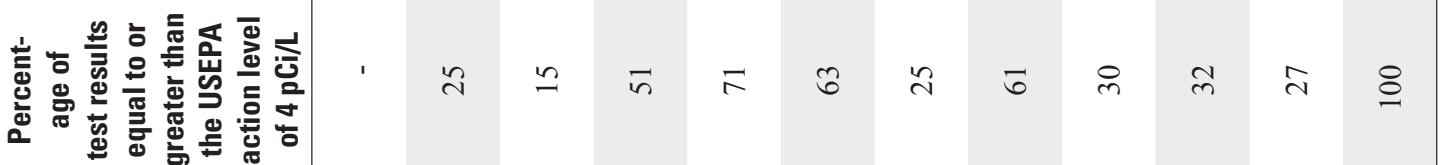

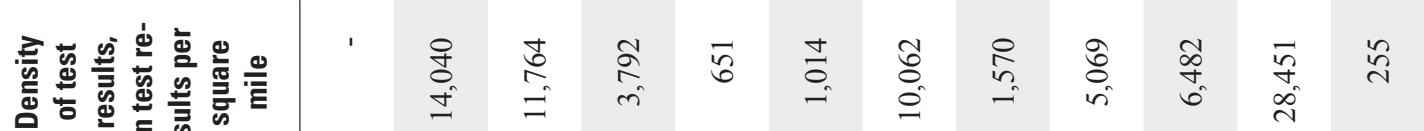

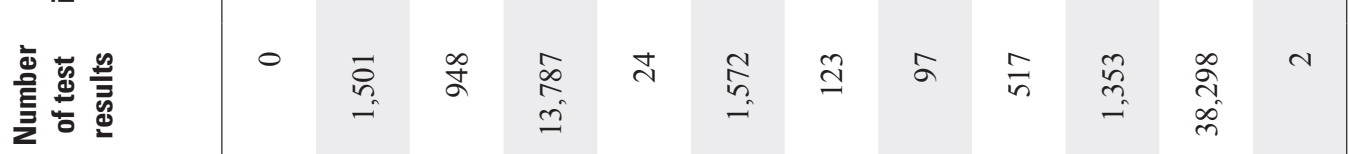

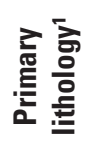

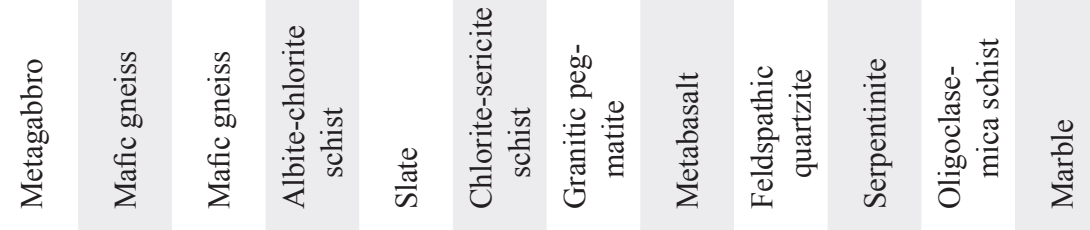

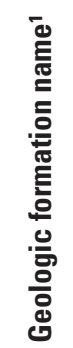

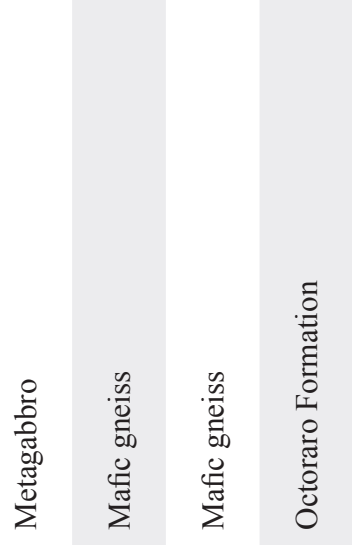

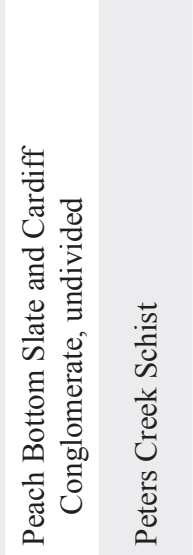

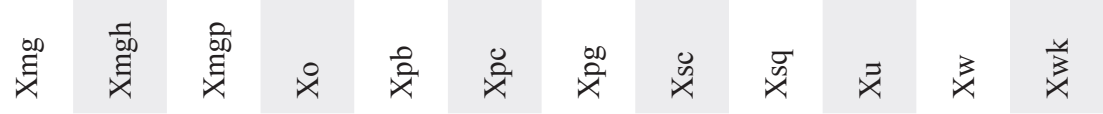


Prepared by the West Trenton Publishing Service Center

For additional information, write to:

Director

U.S. Geological Survey

Pennsylvania Water Science Center

215 Limekiln Road

New Cumberland, Pa. 17070

or visit our Web site at:

http://pa.water.usgs.gov/ 


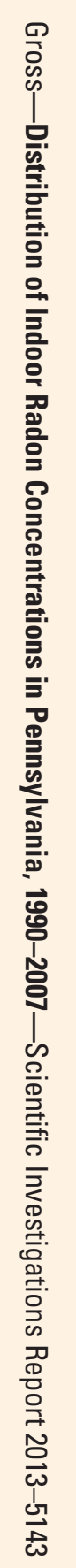

